\title{
A Multilevel Modeling Analysis of the Determinants and Cross-regional Variations of HIV Testing in Ethiopia: Ethiopian DHS 2011
}

Tesfay Gidey Hailu*

School of Interdisciplinary, Department of Statistics, Addis Ababa Science and Technology University, Addis Ababa, Ethiopia

\begin{abstract}
Background: Determinants of HIV testing can be affected at both individual and community levels but most studies in Ethiopia did not assume any clustering effect hence the estimates will often be biased.

Methods: Given the hierarchical nature of the survey population, that is; Ethiopian Demographic and Health Survey (EDHS2011), multilevel modeling approach was used.

Results: About $4.07 \%(6.68 \%)$ of the total variation on ever being tested for HIV was attributable to region-level factors and $17.27 \%(18.45 \%)$ was attributable to cluster level factors among men (women) respectively.

Conclusion: Random effects are useful for modeling intra-cluster correlation; that is, observations in the same cluster were correlated because they share common cluster-level random effects. This study hence will help to notify national efforts targeting on specific population who mostly under-utilized HIV testing services as well as to identify key geographic areas for further investigation. In line with this, the strengthening of the health programs on advocating the benefits of HIV testing through mass media, integrating family planning services with HIV testing, concentrating on both men and women in the age groups of 20 to 34 years old, targeting on Somali region and Nuwer ethnic group while designing services would greatly improve the proportion of HIV testing. Moreover, efficient distribution of health care facilities offering HIV testing services among women urban and rural areas residents are required.
\end{abstract}

Keyword: Determinants; Contextual and individual factors; HIV testing; Multilevel modeling

\section{Background}

Expanding access to HIV counseling and testing (HCT) and antiretroviral treatment services help globally to reduce morbidity and mortality in people living with HIV/ AIDS [1]. To increase access to HIV testing, WHO recommended that population with stronger desire for HCT would be a reasonable priority target to be reached and served by HCT programs [2]. Despite the global coverage for HIV testing remains low; it has helped millions of people to learn their HIV status [3,4]. World Health Organization (WHO) (2004) has estimated that only $5 \%$ of people living with HIV/AIDS are aware of their status worldwide and this is because of people didn't get testing for HIV [5]. Therefore, promoting early detection of HIV infection through HIV testing has been an important public health priority [6]. Furthermore, late detection of HIV infection is a burden for both individuals and society since it is associated with increased morbidity, mortality and probability of transmission [7].

Despite the potential benefits of HIV testing, utilization is often poor in SSA regardless of the availability of the services [8,9]. Ethiopia is one of the countries in SSA that have been affected by a generalized HIV/ AIDS epidemic [10]. Thus, Ethiopia has adopted early HIV testing as one of the key strategies in the HIV/AIDS prevention and control programs for the larger community after the national HIV/ AIDS policy was launched in 1998 [10]. Regardless of the various efforts made to implement HIV prevention activities [11], HIV testing is a critical issue among adults in Ethiopia though there is a good progress compared to the reports in EDHS 2005. According to the 2011 Ethiopia Demographic and Health Survey about 61 percent of women and 59 percent of men have never been tested for HIV [12].

A descriptive analysis made by the 2011 EDHS has reported that the rates of HIV testing are varying by different demographic factors, socio economic variations and HIV risky behaviors in Ethiopia [12].
This variations of HIV testing observed among regions, place of residence, sex and other factors calls for continued efforts to improve understanding of factors associated with HIV testing in Ethiopia to identify target groups for specific interventions using some advanced statistical method [12].

Several studies in various settings have examined determinants associated with HIV testing. A study conducted using data from 49 primarily low and middle-income countries that administered the coverage module of the 2002-2003 World Health Survey has examined income-related inequalities in voluntary and counseling HIV testing. This study revealed that HIV testing was more likely among higher income quintiles and in countries with higher GDP [13]. Studies of socioeconomic status and HIV testing have also indicated that there is a consistent relationship between income and access to HIV testing [14]. This might justify that the costs of the actual HIV testing and transportation to and from the testing site may hinder low-income individuals from being tested. Moreover, higher income individuals consistently report superior access to testing and health-care services in general $[15,16]$.

Other studies; had also analyzed that the barriers of HIV testing at the individual level [17-20] respectively. These studies have shown that the rate of HIV testing in Sub-Saharan Africa are low (less than

*Corresponding author: Tesfay Gidey Hailu, School of Interdisciplinary Department of Statistics, Addis Ababa Science and Technology University, Addis Ababa, Ethiopia, Tel: (+251) 01-189-6144; E-mail: tesfaygdey@yahoo.com

Received October 07, 2015; Accepted December 11, 2015; Published December 21, 2015

Citation: Hailu TG (2016) A Multilevel Modeling Analysis of the Determinants and Cross-regional Variations of HIV Testing in Ethiopia: Ethiopian DHS 2011. J Biom Biostat 7: 277. doi:10.4172/2155-6180.1000277

Copyright: (c) 2016 Hailu TG. This is an open-access article distributed under the terms of the Creative Commons Attribution License, which permits unrestricted use, distribution, and reproduction in any medium, provided the original author and source are credited. 
$30 \%$ ) and vary a lot depending on the context (from $2 \%$ to $27 \%$ ). The most important predictors of HIV testing at the individual level highlighted by qualitative and quantitative methods are socioeconomic characteristics, gender-related barriers, education, perceived risk, spousal communication, awareness of treatment, HIV knowledge, characteristics of test sites (distance, quality of test) and stigma [17-20].

Nevertheless of these studies have identified several individual and country level variables that could influence the rate of HIV testing, direct comparison between individual studies is often unrealistic since these studies performed in different national contexts as well as it may not include similar measures or adjust for the same variables. However, previous researches on HIV testing support some general findings on the role of individual and country level factors. And it has been shown to be an effective and cost-effective strategy to change risk behaviors in developing countries [21,22].

Another drawback of these some studies has been the use of standard logistic regression analysis that ignores clustering and the hierarchical structure of data in the population. In a country where, the health system allows high level of decentralization; like Ethiopia federal and democratic republic government, one might think that the variations in health policies and priorities could be observed. In line with this, the health services, for example health equity, quality service, confidentiality and proximity / distance to health institutions may affect HIV testing.

This study hence used a three-level random intercept logistic model to estimate the effect of unobserved characteristics of cluster and region of the respondent on the likelihood of ever being tested for HIV, i.e., based on nested sources of variability. This multilevel approach provides critical evidence on current barriers to HIV testing and suggests policies which could improve the proportion of participants in HIV testing. In summary, this study addressed the following research questions: What are the individual and contextual determinants that affect HIV testing? Which determinants (individual or community level) are influential for HIV testing? Compare whether there is sexual difference on HIV testing (i.e. which sex is more and/or less likely to be tested for HIV testing?).

\section{Methods}

\section{Study area}

This study is conducted in Ethiopia.

\section{Data source}

This study is based on secondary data analysis of the existing data from Ethiopian DHS 2011; the most recent national dataset on HIV testing (for both men and women) [12]. The sample was selected using a stratified, two-stage cluster design and EAs were the sampling units for the first stage. The hierarchical structure (three-level data structure) of the study data among both men and women are described in Figures 1 and 2.

\section{Data transformation}

The HIV testing datasets of men and women which were used for this study were prepared separately; hence, these databases have been integrated into one database in order to make sexual comparison with respect to HIV testing. Hence, in order to make the analysis simple and cost- effective the study variables needed to be defined in appropriate manner. Therefore, HIV/AIDS-related knowledge index was built from the answers to eight questions; three questions on knowledge of HIV prevention and five on misconceptions about modes of HIV transmission. Five questions that reflected negative attitudes towards to people living with HIV/AIDS were also used to create a stigma index as presented in Tables 1-5. A variable religion had also six distinct values and later categorized into three distinct values. Ethnicity was also originally with 57 distinct values but it has been converted into ten distinct categories as: Tigrean, Affar, Amara, Gurage, Somalie, Sidama, Nuwer, Welaiyta, Oromo and Others.

\section{The multilevel logistic regression analysis}

The structure of data in the survey population is hierarchical; hence, the clustering effect of the sample's data should be taken into consideration during analysis. In this regard, the units at lower level are individuals (Individuals: level-1) who have been asked to ever

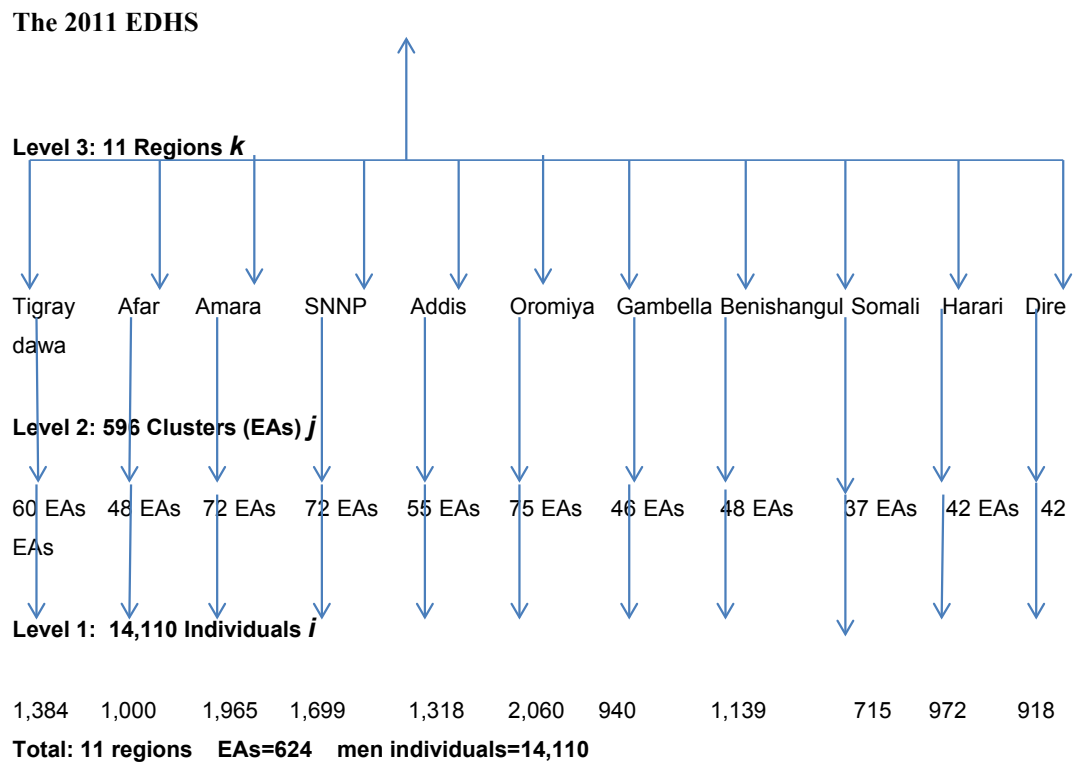

Figure 1: The hierarchical structure (three-level data structure) of the study data in men. 


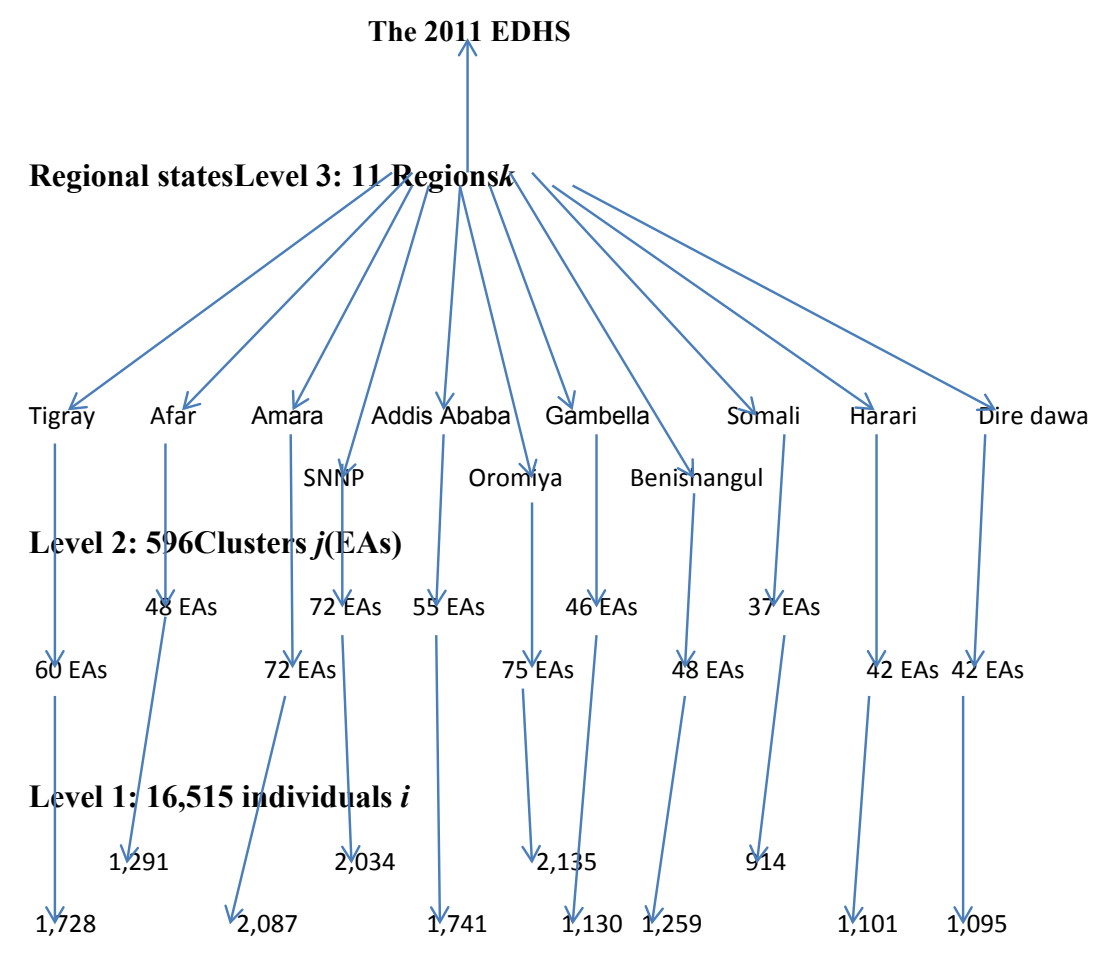

Total: 11 regions EAs=596women individuals=16,515

Figure 2: The hierarchical structure (three-level data structure) of the study data in women.

been tested for HIV i.e. both men aged 15-59 and women 15-49 years old and who are nested within units at higher level (clusters: level-2) and the clusters are again nested within units at the next higher level (regions: level-3). This may indicate that, the probabilities of being tested for HIV are not independent for those of women and /or men who came from same community. The outcome variable in this study is "ever been tested for HIV" which is a binary. The functional form of the three-level random intercept logistic regression can be expressed as described in Rabe-Hesketh and Skrondal [23]:

$$
\operatorname{logit}\left\{P\left(y_{i j k}=1 \mid X_{i j k}, \xi_{j k}^{(2)}, \xi_{k}^{(3)}\right)\right\}=\boldsymbol{X}_{i j k}^{\prime} \boldsymbol{\beta}+\xi_{j k}^{(2)}+\xi_{k}^{(3)}
$$

where $y_{i j k}$ is the probability of being tested for HIV for an individual $i$, in the $j^{\text {th }}$ cluster in the $k^{\text {th }}$ region of Ethiopia; $\boldsymbol{X}_{i j k}^{\prime}$ is row vector of characteristics which may be defined at the individual $i$, who is living in cluster $j^{\text {th }}$ located at $\mathrm{k}^{\text {th }}$ region of the country; $\beta$ is a $1 \mathrm{X}(\mathrm{P}+$ 1) column vector of regression parameter estimates; and the quantities $\xi_{j k}^{(2)}$ and $\xi_{k}^{(3)}$ are the random intercept terms for level 2 (the cluster) and level 3 (region) respectively. In this case, the random-intercept terms denoted that the combined effect of all unobserved heterogeneity which are excluded at cluster-level and regional-level that may affects HIV testing behavior of individuals in some clusters and regions. Therefore, the random-intercepts represent unobserved heterogeneity in the overall response. These are assumed to have normal distribution with mean zero and variances $\psi^{(2)}$ and $\psi^{(3)}$ [23]. That is,

$\left(\xi_{k}^{(3)} \mid X_{i j k}\right) \sim N\left(0, \psi^{(3)}\right) \rightarrow$ the variance component at regions level given any covariate is independent across the regions.

$$
\left(\xi_{j k}^{(2)} \mid X_{i j k}, \xi_{k}^{(3)}\right) \sim N\left(0, \psi^{(2)}\right) \rightarrow \text { the variance component at }
$$

- cluster level given any covariate is independent across the clusters and regions. It is clear that the variance component at regions $\psi^{(3)}$ is the residual between regions. Similarly, the variance component at clusters $\psi^{(2)}$ is the residual between clusters nested with in regions.

The variance components estimate for both region and cluster levels have been used to calculate intra-unit correlation coefficients in order to examine the extent to which how HIV testing behavior of individuals was associated for those who live in clusters nested in regions of the country, before and after taking into account the effect of significant covariates. Since individuals within the same clusters are also within the same region, the intra-cluster correlation includes regional variances [24]. Thus, the intra-cluster $\left({ }^{\rho}(2)\right)$ and intra-region $(\rho(3))$ correlation coefficients are, respectively, given by

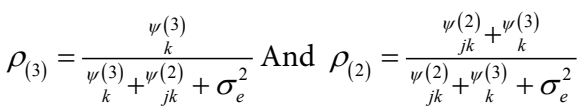

Where $\underset{k}{\psi(3)}$ denotes that the total variance at region level; $\underset{j k}{\psi(2)}$ is the total variance at cluster level; and $\sigma_{e}^{2}$ is the total variance at individual level. In multilevel logistic regression model, the residuals at individuals level (level 1) are represented by $e_{i j k}$ and assumed to have a standard logistic distribution with mean zero and variance $\left(V\left(e_{i j k}\right)=\pi^{2} / 3\right)$, where $\pi$ is the constant 3.1416 [25].

\section{Conceptual analytical framework}

Different sets of factors were assessed to examine determinants that could explain the variation of HIV testing experienced by individuals at regional and cluster levels and their interrelationships among factors as presented in the schema of Figure 3. 
Citation: Hailu TG (2016) A Multilevel Modeling Analysis of the Determinants and Cross-regional Variations of HIV Testing in Ethiopia: Ethiopian DHS 2011. J Biom Biostat 7: 277. doi:10.4172/2155-6180.1000277

Page 4 of 15

\begin{tabular}{|c|c|c|c|c|c|c|}
\hline \multirow{2}{*}{ S.No } & \multirow[b]{2}{*}{ Characteristics } & \multirow[b]{2}{*}{ Category } & \multicolumn{2}{|c|}{ Men } & \multicolumn{2}{|c|}{ Women } \\
\hline & & & $\mathbf{n}$ & $\%$ & $\mathrm{n}$ & $\%$ \\
\hline \multirow{4}{*}{1} & \multirow{4}{*}{ Marital status } & Married & 7,930 & 56.20 & 10,204 & 61.79 \\
\hline & & Divorced & 298 & 2.11 & 922 & 5.58 \\
\hline & & Widowed & 98 & 0.69 & 581 & 3.52 \\
\hline & & Not married & 5,784 & 40.99 & 4,808 & 29.11 \\
\hline \multirow{3}{*}{2} & \multirow{3}{*}{ Religion } & Christian & 8,479 & 60.09 & 10,108 & 61.20 \\
\hline & & Muslim & 5,316 & 37.68 & 6,170 & 37.36 \\
\hline & & Other & 315 & 2.23 & 237 & 1.44 \\
\hline \multirow{2}{*}{3} & \multirow{2}{*}{$\begin{array}{l}\text { Place of } \\
\text { residence }\end{array}$} & Rural & 9,894 & 70.12 & 11,186 & 67.73 \\
\hline & & Urban & 4,216 & 29.88 & 5,329 & 32.27 \\
\hline \multirow{4}{*}{4} & \multirow{4}{*}{$\begin{array}{l}\text { Highest-level of } \\
\text { education }\end{array}$} & No education & 4,449 & 31.53 & 8,278 & 50.12 \\
\hline & & Primary & 6,671 & 47.28 & 5,858 & 35.47 \\
\hline & & Secondary & 1,626 & 11.52 & 1,395 & 8.45 \\
\hline & & Higher & 1,364 & 9.67 & 984 & 5.96 \\
\hline \multirow{5}{*}{5} & \multirow{5}{*}{ Wealth index } & Poorest & 2,847 & 20.18 & 3,711 & 22.47 \\
\hline & & Poorer & 2,109 & 14.95 & 2,402 & 14.54 \\
\hline & & Middle & 2,154 & 15.27 & 2,268 & 13.73 \\
\hline & & Richer & 2,404 & 17.04 & 2,505 & 15.17 \\
\hline & & Richest & 4,596 & 32.57 & 5,629 & 34.08 \\
\hline \multirow{9}{*}{6} & \multirow{9}{*}{ Age group } & $15-19$ & 2,832 & 20.07 & 3,835 & 23.22 \\
\hline & & $20-24$ & 2,330 & 16.51 & 3,022 & 18.30 \\
\hline & & $25-29$ & 2,274 & 16.12 & 3,185 & 19.29 \\
\hline & & $30-34$ & 1,682 & 11.92 & 2100 & 12.72 \\
\hline & & $35-39$ & 1,579 & 11.19 & 1,958 & 11.86 \\
\hline & & $40-44$ & 1,210 & 8.58 & 1314 & 7.96 \\
\hline & & $45-49$ & 961 & 6.81 & 1,101 & 6.67 \\
\hline & & $50-54$ & 730 & 5.17 & - & - \\
\hline & & $55-59$ & 512 & 3.63 & - & - \\
\hline \multirow{10}{*}{7} & \multirow{10}{*}{ Ethnicity } & Tigrean & 1,521 & 10.78 & 1,838 & 11.13 \\
\hline & & Affar & 771 & 5.46 & 1,055 & 6.39 \\
\hline & & Amara & 3,618 & 25.64 & 4,232 & 25.63 \\
\hline & & Gurage & 555 & 3.93 & 692 & 4.19 \\
\hline & & Somalie & 803 & 5.69 & 969 & 5.87 \\
\hline & & Sidama & 366 & 2.59 & 380 & 2.30 \\
\hline & & Oromo & 3,547 & 25.14 & 3,853 & 23.33 \\
\hline & & Nuwer & 241 & 1.71 & 364 & 2.20 \\
\hline & & Welaiyta & 303 & 2.15 & 344 & 2.08 \\
\hline & & Others & 2,385 & 16.90 & 2,788 & 16.88 \\
\hline
\end{tabular}

Table 1: Distribution of socio demographic characteristics related to HIV testing, Ethiopia, 2014.

\section{Results and analysis}

The HIV testing datasets contained 14,110 (46\%) participants of men and $16,515(54 \%)$ participants are women. The detailed socio demographic and/or culture of the participants with respect to ever been tested for HIV are described in Tables 1-5. Figures 4 and 5 also shows that the variations of HIV testing observed among men and women across regions in Ethiopia.

\section{The Univariate Multilevel Logistic Regression}

Univariate multilevel logistic model was first fitted on HIV testing dataset (for men and women) to select covariates which then will be used as covariates at the time of multilevel analysis. The level of significance was fixed to be less than $5 \%$ for drawing any kind of conclusion about the predictors in which the model is different from univariate multilevel model. The first step examined the null model (empty model with no predictor) was first fitted to measure the overall probability of an individual (men and women) was being tested for HIV without an adjustment for predictors. The second step included first the univariate multilevel logistic analysis and then random slope multilevel univariate analysis for each of the selected explanatory variables. The third step considered a model building for three levels multiple multilevel logistic regression analysis. The Wald $\chi 2$ test was

\begin{tabular}{|c|c|c|c|c|c|c|}
\hline \multirow{3}{*}{ S.No } & \multirow{3}{*}{ Characteristics } & \multirow{3}{*}{ Category } & \multicolumn{4}{|c|}{ HIV Testing } \\
\hline & & & \multicolumn{2}{|c|}{$\operatorname{Men}(n=14,110)$} & \multicolumn{2}{|c|}{$\begin{array}{c}\text { Women }(n= \\
16,515)\end{array}$} \\
\hline & & & Yes & No & Yes & No \\
\hline \multirow{11}{*}{1} & \multirow{11}{*}{ Region } & Tigray & 53.90 & 46.10 & 59.43 & 40.57 \\
\hline & & Affar & 29.40 & 70.60 & 23.78 & 76.22 \\
\hline & & Amhara & 40.76 & 59.24 & 33.97 & 66.03 \\
\hline & & SNNP & 41.32 & 58.68 & 33.19 & 66.81 \\
\hline & & Addis Ababa & 59.56 & 40.44 & 65.94 & 34.06 \\
\hline & & Oromiya & 33.64 & 66.36 & 35.36 & 64.64 \\
\hline & & Gambella & 45.85 & 54.15 & 36.28 & 63.72 \\
\hline & & $\begin{array}{c}\text { Benishangul } \\
\text { Gumuz }\end{array}$ & 40.21 & 59.79 & 35.82 & 64.18 \\
\hline & & Somali & 17.20 & 82.80 & 10.07 & 89.93 \\
\hline & & Harari & 42.08 & 57.92 & 57.31 & 42.69 \\
\hline & & Dire dawa & 59.80 & 40.20 & 64.84 & 35.16 \\
\hline \multirow{2}{*}{2} & \multirow{2}{*}{$\begin{array}{l}\text { Place of } \\
\text { residence }\end{array}$} & Rural & 34.92 & 65.08 & 30.46 & 69.54 \\
\hline & & Urban & 60.15 & 39.85 & 34.17 & 65.83 \\
\hline
\end{tabular}

Table 2: Percentage of HIV testing by region and place of residence, among men and women, Ethiopia, 2014.

\begin{tabular}{|c|c|c|c|c|}
\hline \multirow{2}{*}{ S.No } & \multirow{2}{*}{ Characteristics } & \multirow[b]{2}{*}{ Category } & Men & \multirow{2}{*}{$\begin{array}{l}\text { Women } \\
\text { n (\%) }\end{array}$} \\
\hline & & & n (\%) & \\
\hline 1 & $\begin{array}{l}\text { HIVIAIDS } \\
\text { knowledge } \\
\text { indicators }\end{array}$ & & & \\
\hline \multirow{24}{*}{$\begin{array}{c}\text { Reduce } \\
\text { the risk of } \\
\text { getting HIV } \\
\text { by }\end{array}$} & \multirow{3}{*}{$\begin{array}{l}\text { Using Condom } \\
\text { during Sex }\end{array}$} & Yes & $11,373(80.60)$ & 9,667 (58.53) \\
\hline & & No & $1,664(11.79)$ & $3,296(19.96)$ \\
\hline & & Don't know & $1,073(7.60)$ & $3,552(21.51)$ \\
\hline & \multirow{3}{*}{$\begin{array}{l}\text { Not having sex } \\
\text { at all }\end{array}$} & Yes & $12,066(86.71)$ & 11,239 (70.69) \\
\hline & & No & $1,485(10.67)$ & $3,229(20.31)$ \\
\hline & & Don't know & $365(2.62)$ & 1,430 (8.99) \\
\hline & \multirow{3}{*}{$\begin{array}{l}\text { Having one sex } \\
\text { partner only }\end{array}$} & Yes & $10,163(72.03)$ & $10,257(62.11)$ \\
\hline & & No & $2,863(20.29)$ & $3,973(24.06)$ \\
\hline & & Don't know & $1,084(7.68)$ & $2,285(13.84)$ \\
\hline & \multirow{3}{*}{$\begin{array}{l}\text { Sharing food with } \\
\text { HIVIAIDS infected } \\
\text { person }\end{array}$} & Yes & $1,460(10.35)$ & $15,442(93.50)$ \\
\hline & & No & $12,132(85.98)$ & $591(3.58)$ \\
\hline & & Don't know & $518(3.67)$ & $482(2.92)$ \\
\hline & \multirow{3}{*}{$\begin{array}{c}\text { Healthy looking } \\
\text { Person can have } \\
\text { HIV }\end{array}$} & Yes & $10,982(77.83)$ & $10,513(63.66)$ \\
\hline & & No & $1,898(13.45)$ & $3,933(23.81)$ \\
\hline & & Don't know & 1,230 (8.72) & 2,069 (12.53) \\
\hline & \multirow{3}{*}{$\begin{array}{l}\text { Can get HIV by } \\
\text { super natural? }\end{array}$} & Yes & $2,850(20.20)$ & $3,475(21.04)$ \\
\hline & & No & $10,688(75.75)$ & $11,766(71.24)$ \\
\hline & & Don't know & $572(4.05)$ & $1,274(7.71)$ \\
\hline & \multirow{3}{*}{$\begin{array}{l}\text { Can get HIV from } \\
\text { mosquito bite }\end{array}$} & Yes & $3,424(24.27)$ & $4,165(25.22)$ \\
\hline & & No & $8,823(62.53)$ & $9,139(55.34)$ \\
\hline & & Don't know & $1,863(13.20)$ & $3,211(19.44)$ \\
\hline & \multirow{3}{*}{$\begin{array}{l}\text { Can get HIV by } \\
\text { sharing sharp } \\
\text { materials }\end{array}$} & Yes & $13,717(97.21)$ & $15,442(93.5)$ \\
\hline & & No & $215(1.52)$ & 591 (3.58) \\
\hline & & Don't know & 178 (1.26) & $482(2.92)$ \\
\hline
\end{tabular}

Table 3: Distribution of HIV Testing in relation to HIVIAIDS-related knowledge among men and women in Ethiopia, 2014. 


\begin{tabular}{|c|c|c|c|}
\hline \multirow{2}{*}{ Characteristics } & & Men & Women \\
\hline & Category & n (\%) & n (\%) \\
\hline \multicolumn{4}{|l|}{$\begin{array}{l}\text { Risky sexual behaviour } \\
\text { indicators }\end{array}$} \\
\hline \multirow{3}{*}{ Had any STIs in last 12 months } & Yes & $87(0.62)$ & $85(0.51)$ \\
\hline & No & 14,016 (99.33) & $16,426(99.46)$ \\
\hline & Don't know & $7(0.05)$ & $4(0.02)$ \\
\hline \multirow{3}{*}{$\begin{array}{l}\text { Had genital ulcer in last } 12 \\
\text { months }\end{array}$} & Yes & $83(99.28)$ & $181(1.10)$ \\
\hline & No & $14,008(99.28)$ & $16,173(97.93)$ \\
\hline & Don't know & $19(0.13)$ & $161(0.97)$ \\
\hline \multirow{3}{*}{$\begin{array}{l}\text { Had genital discharge last } 12 \\
\text { months }\end{array}$} & Yes & $164(1.16)$ & $168(1.02)$ \\
\hline & No & $13,926(98.70)$ & $16,068(97.29)$ \\
\hline & Don't know & $20(0.14)$ & $279(1.69)$ \\
\hline \multirow{3}{*}{$\begin{array}{l}\text { Wife justified asking husband to } \\
\text { use condom if he had STI }\end{array}$} & Yes & $12,154(86.14)$ & $11,133(67.41)$ \\
\hline & No & $1,462(10.36)$ & $3,391(20.53)$ \\
\hline & Don't know & $494(3.50)$ & $1,991(12.06)$ \\
\hline \multirow{2}{*}{ Ever took alcohol during sex } & Yes & $7,223(51.19)$ & $6,334(38.35)$ \\
\hline & No & $6,887(48.81)$ & $10,181(61$. \\
\hline
\end{tabular}

Table 4: Distribution of HIV Testing in relation to HIVIAIDS risky sexual behaviours among men and women in Ethiopia, 2014.

\begin{tabular}{|c|c|c|c|}
\hline Characteristics & & Men & Women \\
\hline & Category & n (\%) & n (\%) \\
\hline \multicolumn{4}{|c|}{ HIVIAIDS related stigma indicators } \\
\hline \multirow[t]{2}{*}{ Ever heard HIVIAIDS } & Yes & $13,916(98.63)$ & $15,896(96.25)$ \\
\hline & No & $194(1.37)$ & $619(3.75)$ \\
\hline \multirow{3}{*}{$\begin{array}{l}\text { Would want HIV infection } \\
\text { remain secret in family }\end{array}$} & Yes & $4,99(35.39)$ & $6,354(38.47)$ \\
\hline & No & $8,813(62.46)$ & $9,662(58.50)$ \\
\hline & Don't know & $304(2.15)$ & 499 (3.02) \\
\hline \multirow{3}{*}{$\begin{array}{l}\text { Willing to care for relatives } \\
\text { with HIV }\end{array}$} & Yes & 12,970 (91.92) & $13,839(83.80)$ \\
\hline & No & $1,016(7.20)$ & $2,473(14.97)$ \\
\hline & Don't know & $124(0.88)$ & $203(1.23)$ \\
\hline \multirow{3}{*}{$\begin{array}{l}\text { Would allow female teacher } \\
\text { with HIV continue teaching }\end{array}$} & Yes & $9,982(70.74)$ & $10,252(62.08)$ \\
\hline & No & $3,661(25.95)$ & $5,022(30.41)$ \\
\hline & Don't know & 467 (3.31) & $1,241(7.51)$ \\
\hline \multirow{2}{*}{$\begin{array}{l}\text { Would buy Vegetables from } \\
\text { Vendor with AIDS }\end{array}$} & Yes & $7,336(51.99)$ & $6,345(38.42)$ \\
\hline & No & $6,774(48.01)$ & $10,170(61.58)$ \\
\hline
\end{tabular}

Table 5: Distribution of HIV Testing in relation to HIVIAIDS stigma towards to an infected individual among men and women in Ethiopia, 2014.

used to determine the significance of each model as a whole as well as to determine significance of individual $\beta$ coefficients. STATA version 11.1 was used to analyze the data.

\section{Multilevel Logistic Model: The random Intercept Only}

Firstly, an empty model with no predictors was fitted to HIV testing data set and this means that a random intercept-only model could predicts the probability of an individual whether an individual has ever been tested for HIV. The functional form of the model is given by:

$$
\operatorname{logit}\left\{y_{i j k}=1\right\}=\ln \left(\frac{y_{i j k}}{1-y_{i j k}}\right)=\beta_{0 j k}=\beta_{0}+\xi_{0 k}^{(3)}+\xi_{j k}^{(2)}
$$

The parameters under random effect displayed in Table 6 are the estimated variances of the random intercepts at both levels (level 2: cluster and 3: region) for fitting a model of three-level random intercept-only. The fixed effect term (fixed intercept) is estimated to be $\beta_{\circ}=0.4245$ indicated that the average of all regions or all clusters for experiencing HIV testing. Moreover, the estimates for the random effects of the three-level intercept-only model explained that the unique effect up on the HIV testing behavior of an individual that came from each region (level 3) and cluster (level 2). The percentage of observed variation in ever been tested for HIV attributable to regional level is found by dividing the variance for the random effect of the region by the total variance. This means that the intra-correlation coefficient (ICC) for men and women respectively will be given as follows:

$$
\begin{aligned}
& \rho_{(3)}=\frac{\psi_{k}^{(3)}}{\psi_{k}^{(3)}+{ }_{j k}^{\psi(2)}+\sigma_{e}^{2}}=\frac{.41930}{.4193+.8591+\frac{\pi^{2}}{3}}=0.092 \% \text { And } \\
& \rho_{(2)}=\frac{\psi_{j k}^{(2)}+{ }_{k}^{\psi(3)}}{\psi_{j k}^{(2)}+{ }_{k}{ }_{k}^{(3)}+\sigma_{e}^{2}}=\frac{.8591+.41930}{.4193+.8591+\frac{\pi^{2}}{3}}=0.2792 \% \rightarrow \rho_{(3)} \text { and } \rho_{(2)}
\end{aligned}
$$

denotes for the ICC of HIV testing among men at regional and cluster level. And $\rho_{(3)}=0.19$ and $\rho_{(2)}=0.443 \rightarrow \rho_{(3)}$ and $\rho_{(2)}$ denotes for the ICC of HIV testing among women at regional and cluster level (Table 6). When the multilevel model (that is random intercept only model) is applied the expected log-odds of ever been tested for HIV is 0.4283 , which is corresponding to an odds of $\exp (-0.4283)=0.6516$ as seen in Table 6 . The $95 \%$ confidence interval for $\beta_{0 j k}$ is $-0.4283 \pm 1.96 * \sqrt{1.2784}=(-2.259,2.173)$.

This indicates that the multilevel effects (that is the random effects at different levels) would impact the rate of HIV testing to vary from 6.6 percent to 85.7 percent within the regions (clusters nested with in regions) and no predictor has been included in this model. Moreover, the likelihood ratio test indicated that the random effect model is highly significant in explaining the variation of HIV testing observed among both men and women $(\mathrm{P}$-value $=0.0000<0.05)$. Hence, the random intercept model is better in comparison to standard logistic regression on explaining the variation of HIV testing observed among both men and women (Table 7).

\section{Multilevel Univariate Logistic Model}

A multilevel univariate logistic analysis for both men and women are presented in Table 8 and 9 and each of the multilevel models presents a random intercept (specific effects due to region and cluster) and a fixed slope for the particular variable fitted with the outcome. It has been observed the same results for both men and women with slight variations on their parameter estimates (Table 9).

\section{Multilevel univariate model for random slope}

Random slope univariate model allows the effect that the coefficient of the predictor variable to vary from region to region and from cluster to cluster. The random effects model (with both random intercept and slope) was fitted for two predictors which are wealth index and place of residence. The three-level random model for place of residence and wealth index can be written as below:

$$
\begin{aligned}
& \operatorname{logit}\left\{y_{i j k}=1\right\}=\ln \left(\frac{y_{i j k}}{1-y_{i j k}}\right)=\beta_{0 j k}=\beta_{0}+\beta_{1} P R_{i j k}+ \\
& \beta_{2} W I_{i j k}+\xi_{0 k}^{(3)}+\xi_{0 j k}^{(2)}+\left(\xi_{1 k}+\xi_{1 j k}\right) P R_{i j k}+\left(\xi_{2 k}+\xi_{2 j k}\right) W I_{i j k}
\end{aligned}
$$

Where the additive term $\xi_{0 k}^{(3)}+\xi_{0 j k}^{(2)}+\left(\xi_{1 k}+\xi_{1 j k}\right) P R_{i j k}+\left(\xi_{2 k}+\xi_{2 j k}\right) W I_{i j k}$ is in fact the residual $\left(e_{i j k}\right)$ of the model which is a function of place of residence and wealth index. However, the random slope for place of residence and wealth index were found to be in significant (estimates of the variance components of the two predictors are not greater than 2 times of their standard errors)across both region and cluster level of both men and women. Hence, the random slope model for place of 


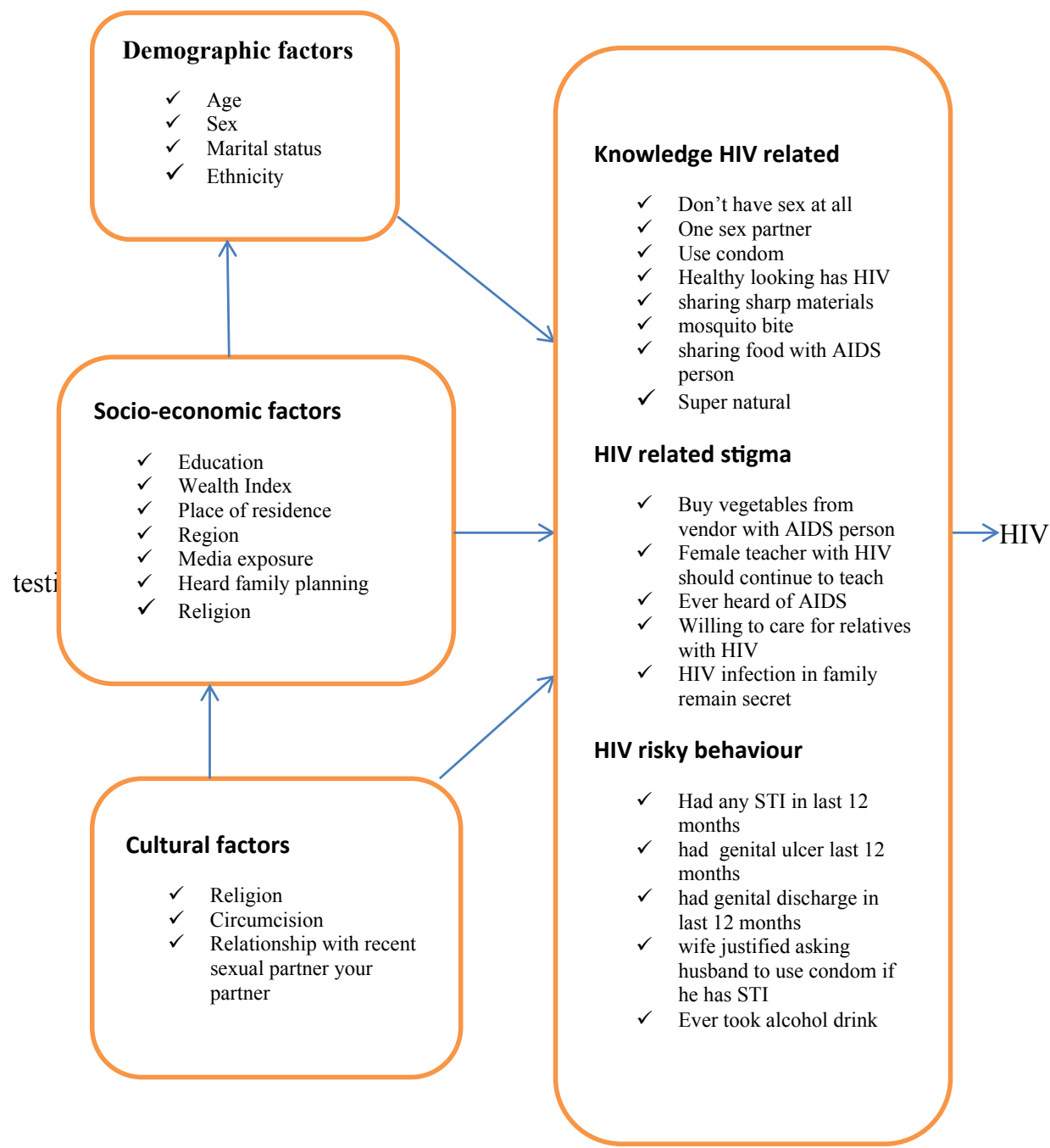

Figure 3: The variation of HIV testing experienced by individuals at regional and cluster levels and their interrelationships among factors as presented in the schema.

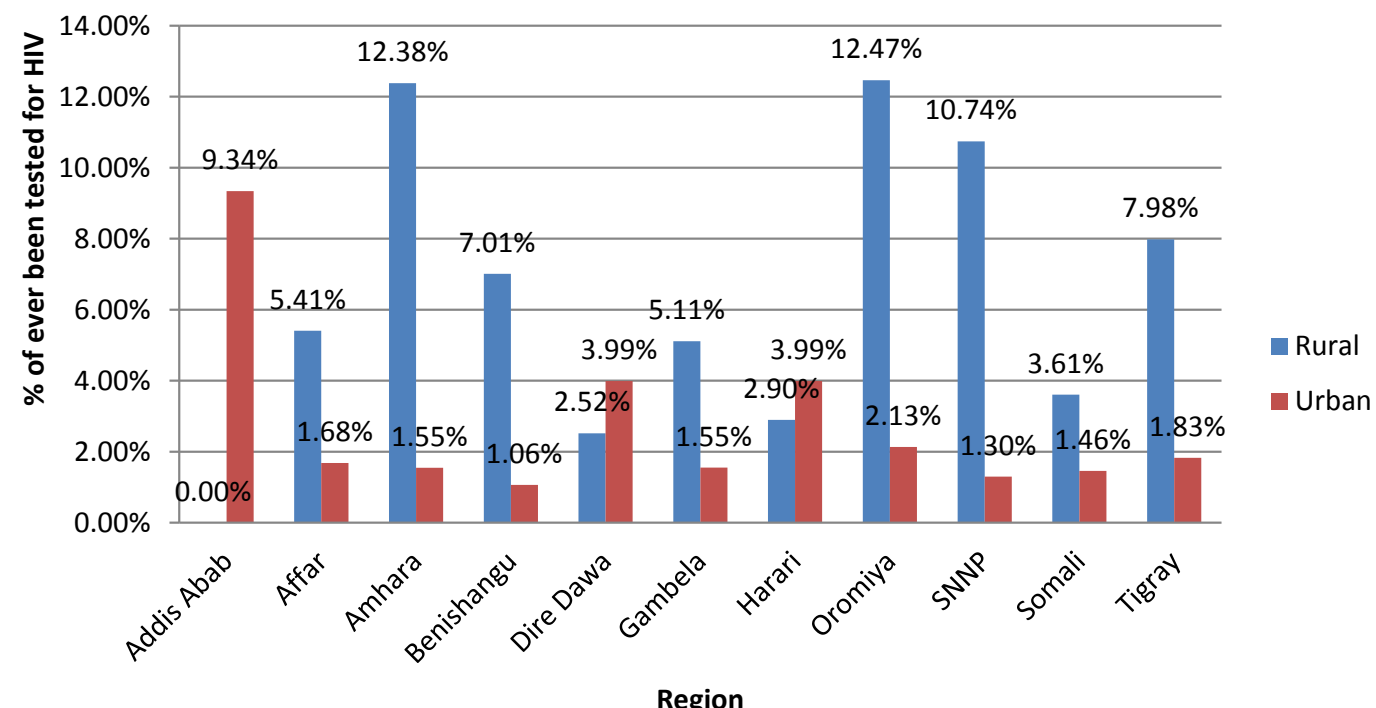

Figure 4: Shows that the variations of HIV testing observed in men across regions in Ethiopia. 
Citation: Hailu TG (2016) A Multilevel Modeling Analysis of the Determinants and Cross-regional Variations of HIV Testing in Ethiopia: Ethiopian DHS 2011. J Biom Biostat 7: 277. doi:10.4172/2155-6180.1000277

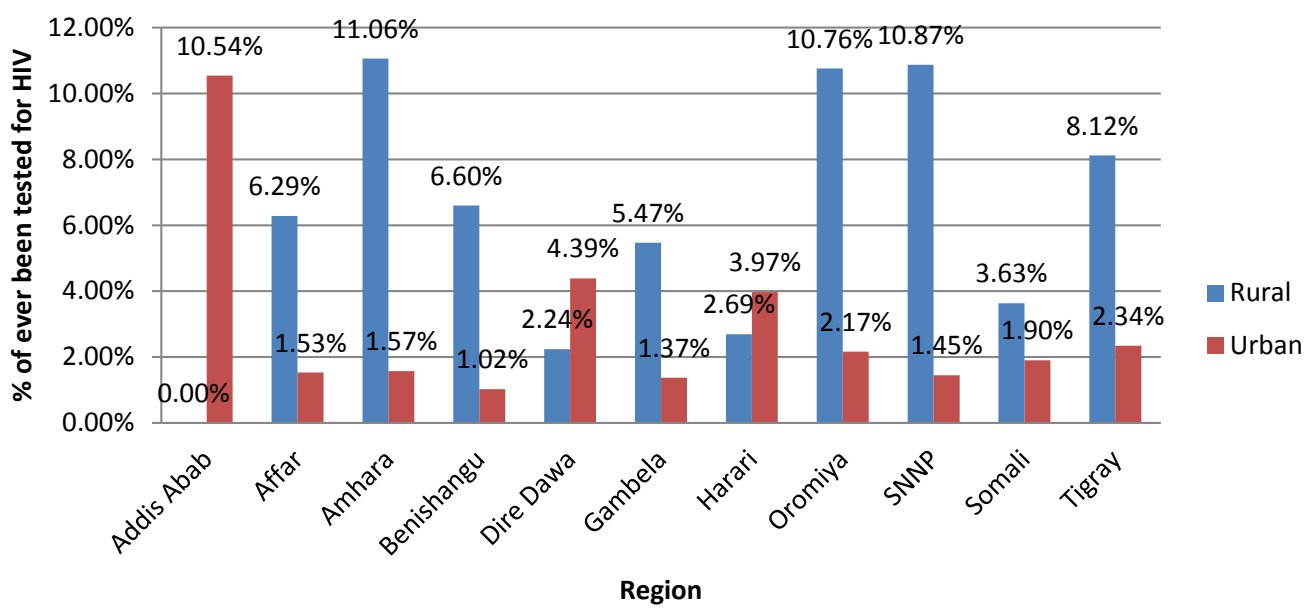

Figure 5: Shows that the variations of HIV testing observed in women across regions in Ethiopia.

\begin{tabular}{|c|c|c|c|c|}
\hline \multirow{3}{*}{ Model effect } & \multicolumn{4}{|c|}{ Multilevel model } \\
\hline & Men & & Women & \\
\hline & Estimates (SE) & [95\% Conf. Interval] & Estimates (SE) & [95\% Conf. Interval] \\
\hline \multicolumn{5}{|l|}{ Fixed effect } \\
\hline Intercept & $-.4283(.2004)^{\star *}$ & {$[-.8211,-.0354]$} & $-.6001(.3298)^{\star *}$ & {$[-1.2467, .0464]$} \\
\hline Random effect Intercept (level 3) & $.4193(.1917)^{\star *}$ & {$[.1711,1.0272]$} & $1.1608(.5173)^{\star *}$ & {$[.4846,2.7803]$} \\
\hline Random effect Intercept (level 2): Region>cluster & $.8591(.0718)^{\star \star}$ & {$[.7293,1.0120]$} & $1.4636(.1127)^{\star *}$ & {$[1.2585,1.7021]$} \\
\hline Variance $\left(\mathrm{e}_{\mathrm{ijk}}\right)$ & $(3.1416)^{2} / 3=3.27$ & & 3.27 & \\
\hline$-2 \log L$ & -8724.444 & & -9767.64 & \\
\hline Deviance & 17448.888 & & & \\
\hline $\mathrm{N}$ & 14,110 & & 16,515 & \\
\hline LR test vs. logistic regression: & \multicolumn{2}{|c|}{$\operatorname{chi} 2(2)=1789.56 \quad$ Prob $>$ chi2 $=0.0000$} & \multicolumn{2}{|c|}{$\operatorname{chi} 2(2)=4035.73 \quad$ Prob $>$ chi $2=0.0000$} \\
\hline
\end{tabular}

Table 6: Parameters estimates and standard errors of an intercept-only multilevel model predicting the probability of being tested for HIV among men and women (S.Es are placed in parentheses).

\begin{tabular}{|l|c|c|c|c|c|}
\hline Men=14,110 & \multicolumn{3}{|c|}{ Observations per group } \\
\hline Group variable & Number of groups & Minimum & Average & Maximum \\
\hline Region & 11 & 715 & 1282.7 & 2060 \\
\hline Cluster number & 596 & 3 & 23.7 & 77 \\
\hline Women=16,515 & & & \multicolumn{2}{|c|}{ Observations per group } \\
\hline Group variable & Number of groups & Minimum & Average & Maximum \\
\hline Region & 11 & 914 & 1501.4 & Integration points \\
\hline Cluster number & 596 & 5 & 27.7 & 7 \\
\hline
\end{tabular}

Table 7: Summary results for both men and women datasets.

residence and wealth index that were being allowed to vary at region or cluster level was not considered any more while fitting the final multiple multilevel model with all significant predictors (Table 10).

\section{Multilevel Multiple Logistic Model}

The multiple logistic of multilevel model is fitted with all the significant predictors, found at multilevel univariate analysis to assess their simultaneous effect on HIV testing. The proposed functional form of the multilevel model is:

$$
\begin{aligned}
& \operatorname{logit}\left\{y_{i j k}=1\right\}=\ln \left(\frac{y_{i j k}}{1-y_{i j k}}\right)=\beta_{0 j k}+\beta_{1} \text { AgeGroup }_{i j k}+\beta_{2 j k} P_{i j k}+ \\
& \beta_{3} \text { EduLev }_{i j k}+\beta_{4} \operatorname{Relgn}_{i j k}+\beta_{5} \text { Ethnic }_{i j k}+\beta_{6 j k} \text { VlthIndex }_{i j k}+\ldots \\
& \text { Where } \beta_{0 j k}=\beta_{0}+\xi_{0 k}^{(3)}+\xi_{0 j k}^{(2)}, \beta_{2 j k}=\beta_{2}+\xi_{2 k}+\xi_{2 j k} \text { and }
\end{aligned}
$$

$$
\beta_{6 j k}=\beta_{6}+\xi_{6 k}+\xi_{6 j k}
$$

The variation of HIV testing among men and women were significant $(\mathrm{p}<0.05)$ at all levels of the hierarchy (individual, cluster and region). It has been also found that the random effects of both cluster and region levels were significant on explaining the variations of HIV testing among both men and women (Tables 11 and 12).

In summary, the random-effects multiple multilevel model results indicated that all the predictors are not equally and effectively defining the characteristics of both men and women for utilizing HIV testing. HIV testing is therefore correlated among women and/or men in the same cluster within each region but the correlation differs from region to region. Despite the more complex model (random intercept and slope model) explains the variations of HIV testing among individuals better than the other model, in this study the variance components for the random slope of both wealth index and place of residence were 
Citation: Hailu TG (2016) A Multilevel Modeling Analysis of the Determinants and Cross-regional Variations of HIV Testing in Ethiopia: Ethiopian DHS 2011. J Biom Biostat 7: 277. doi:10.4172/2155-6180.1000277

Page 8 of 15

\begin{tabular}{|c|c|c|c|c|}
\hline \multirow{2}{*}{ Fixed effects } & \multicolumn{2}{|c|}{ Men $(n=14,110)$} & \multicolumn{2}{|c|}{ Multilevel model } \\
\hline & Estimates (SE) & P-Value & Region (Lev 3) & Cluster (Lev 2) \\
\hline Age group & & & $.4250(.1950)^{\star \star}$ & $.9342(.0773)^{\star *}$ \\
\hline $15-19$ & Ref (1) & & & \\
\hline $20-24$ & $.9081(.0658)$ & 0.000 & & \\
\hline $25-29$ & $1.1543(.0666)$ & 0.000 & & \\
\hline $30-34$ & $1.0139(.0731)$ & 0.000 & & \\
\hline $35-39$ & $.8731(.0735)$ & 0.000 & & \\
\hline $40-44$ & .6689 (.0809) & 0.000 & & \\
\hline $45-49$ & $.6289(.0874)$ & 0.000 & & \\
\hline $50-54$ & $.4494(.0971)$ & 0.000 & & \\
\hline $55-59$ & $.0483(.1159)$ & 0.677 & & \\
\hline Education level & & & $.2905(.1345)^{\star \star}$ & $.6325(.0570)^{\star *}$ \\
\hline No education & Ref (1) & & & \\
\hline Primary & $.6888(.0496)$ & 0.000 & & \\
\hline Secondary & $1.3294(.0753)$ & 0.000 & & \\
\hline Higher & $1.6591(.0845)$ & 0.000 & & \\
\hline $\begin{array}{l}\text { Place of } \\
\text { residence }\end{array}$ & & & $.3222(.1479)^{\star \star}$ & $.5783(.0521)^{\star *}$ \\
\hline Rural & $\operatorname{Ref}(0)$ & & & \\
\hline Urban & $1.3782(.0990)$ & 0.000 & & \\
\hline Religion & & & $.3529(.1633)^{\star *}$ & $.8178(.0692)^{\star *}$ \\
\hline Christian & Ref (1) & & & \\
\hline Muslim & $-.2902(.0652)$ & 0.000 & & \\
\hline Others & $-.4491(.1549)$ & 0.004 & & \\
\hline Ethnicity & & & $.1915(.0928)^{\star *}$ & $.7387(.0642)^{\star *}$ \\
\hline Tigrean & Ref (1) & & & \\
\hline Affar & $-1.5394(.2571)$ & 0.000 & & \\
\hline Amara & $-.1473(.1491)$ & 0.323 & & \\
\hline Guragie & $-.4699(.1793)$ & 0.009 & & \\
\hline Somalie & $-1.5102(.2312)$ & 0.000 & & \\
\hline Sidama & $-.9857(.2895)$ & 0.001 & & \\
\hline Oromo & $-.4998(.1554)$ & 0.001 & & \\
\hline Nuwer & $-1.6162(.3240)$ & 0.000 & & \\
\hline Welaiyta & $-.3239(.2359)$ & 0.170 & & \\
\hline Others & $-.6514(.1589)$ & 0.000 & & \\
\hline Media exposure & & & $.3625(.1666)^{\star \star}$ & $.7605(.0654)^{\star *}$ \\
\hline Yes & Ref (1) & & & \\
\hline No & $1.0182(.0639)$ & 0.000 & & \\
\hline Wealth Index & & & $.2632(.1217)^{\star}$ & $.5032(.0475)^{\star}$ \\
\hline Poorest & $\operatorname{Ref}(1)$ & & & \\
\hline Poorer & $.3923(.0742)$ & 0.000 & & \\
\hline Middle & $.5929(.0755)$ & 0.000 & & \\
\hline Richer & $.9789(.0761)$ & 0.000 & & \\
\hline Richest & $1.7211(.0868)$ & 0.000 & & \\
\hline Marital status & & & $.4541(.2072)^{\star *}$ & $.9244(.0765)^{\star *}$ \\
\hline Not married & $\operatorname{Ref}(0)$ & & & \\
\hline Divorced & $.7144(.1356)$ & 0.000 & & \\
\hline Widowed & $.3600(.2398)$ & 0.133 & & \\
\hline Married & $.4091(.0411)$ & 0.000 & & \\
\hline $\begin{array}{l}\text { Relationship } \\
\text { with most } \\
\text { recent sex } \\
\text { partner }\end{array}$ & & & $.3945(.1808)^{\star \star}$ & $.8301(.0700)^{\star *}$ \\
\hline $\begin{array}{l}\text { Living with } \\
\text { partner }\end{array}$ & $\operatorname{Ref}(0)$ & & & \\
\hline Boy-girl friend & .4678 (.1599) & 0.003 & & \\
\hline Commercial & $.1433(.3119)$ & 0.646 & & \\
\hline Spouse & $-.2006(.1393)$ & 0.150 & & \\
\hline Other & .3967 (.2098) & 0.059 & & \\
\hline
\end{tabular}

\begin{tabular}{|c|c|c|c|c|}
\hline $\begin{array}{l}\text { Hear Family } \\
\text { planning on } \\
\text { Mass Media }\end{array}$ & & & $.3479(.1601)^{\star *}$ & $.7506(.0647)^{\star \star}$ \\
\hline No & $\operatorname{Ref}(0)$ & & & \\
\hline Yes & $.9276(.0447)$ & 0.000 & & \\
\hline $\begin{array}{l}\text { HIV related } \\
\text { knowledge }\end{array}$ & & & $.2826(.1321)^{\star *}$ & $.7481(.0647)^{\star *}$ \\
\hline Low & $\operatorname{Ref}(0)$ & & & \\
\hline High & $.5408(.0915)$ & 0.000 & & \\
\hline comprehensive & $1.0681(.0901)$ & 0.000 & & \\
\hline $\begin{array}{l}\text { HIV related } \\
\text { stigma }\end{array}$ & & & $.3216(.1480)^{\star *}$ & $.6822(.0606)^{\star *}$ \\
\hline No stigma & $\operatorname{Ref}(0)$ & & & \\
\hline Low & $-.4064(.0492)$ & 0.000 & & \\
\hline Moderate & $-1.0235(.0545)$ & 0.000 & & \\
\hline High & $-1.2272(.2029)$ & 0.000 & & \\
\hline $\begin{array}{l}\text { HIV risky } \\
\text { behaviour }\end{array}$ & & & $.4185(.1913)^{\star *}$ & $.8461(.0709)^{\star *}$ \\
\hline No risk & $\operatorname{Ref}(0)$ & & & \\
\hline Some risk & $-.0047(.0473)$ & 0.920 & & \\
\hline High & $-.4583(.0944)$ & 0.000 & & \\
\hline $\begin{array}{l}\text { Knowing Place } \\
\text { for HIV test }\end{array}$ & & & $.2007(.0954)^{\star *}$ & $.5345(.0515)^{\star *}$ \\
\hline No & $\operatorname{Ref}(0)$ & & & \\
\hline Yes & $20.4095(461.10)$ & 0.975 & & \\
\hline
\end{tabular}

** Indicates significant value

Table 8: Parameter estimates and standard errors of univariate multilevel mode predicting the probability of ever been tested for HIV with random intercept and fixed slope among men, Ethiopia (S.Es are placed in parentheses)

\begin{tabular}{|c|c|c|c|c|}
\hline \multirow{2}{*}{ Fixed effects } & \multicolumn{2}{|c|}{ Women $(n=16,515)$} & \multicolumn{2}{|c|}{ Multilevel model } \\
\hline & Estimates (SE) & P-Value & Region (Lev 3) & Cluster (Lev 2) \\
\hline Age group & & & $1.2029(.5362)^{\star *}$ & $1.5413(.1183)^{\star *}$ \\
\hline $15-19$ & Ref $(0)$ & & & \\
\hline $20-24$ & $.9338(.0603)$ & 0.000 & & \\
\hline $25-29$ & $.8437(.0595)$ & 0.000 & & \\
\hline $30-34$ & $.6743(.0675)$ & 0.000 & & \\
\hline $35-39$ & $.5407(.0690)$ & 0.000 & & \\
\hline $40-44$ & $.2849(.0801)$ & 0.000 & & \\
\hline $45-49$ & $-.0602(.0869)$ & 0.488 & & \\
\hline $50-54$ & - & - & & \\
\hline $55-59$ & - & - & & \\
\hline $\begin{array}{c}\text { Education } \\
\text { level }\end{array}$ & & & $.8686(.3894)^{\star *}$ & $1.1484(.0930)^{\star *}$ \\
\hline No education & Ref $(0)$ & & & \\
\hline Primary & $.5240(.0446)$ & 0.000 & & \\
\hline Secondary & $1.0897(.0783)$ & 0.000 & & \\
\hline Higher & $1.5627(.0983)$ & 0.000 & & \\
\hline $\begin{array}{l}\text { Place of } \\
\text { residence }\end{array}$ & & & $.7814(.3521)^{\star \star}$ & $.9350(.0769)^{\star \star}$ \\
\hline Rural & $\operatorname{Ref}(0)$ & & & \\
\hline Urban & $1.8164(.1185)$ & 0.000 & & \\
\hline Religion & & & $1.0797(.4822)^{\star *}$ & $1.4120(.1095)^{\star *}$ \\
\hline Christian & Ref $(0)$ & & & \\
\hline Muslim & $-.2440(.0674)$ & 0.000 & & \\
\hline Others & $-.9970(.2246)$ & 0.000 & & \\
\hline Ethnicity & & & $.7545(.3446)^{\star *}$ & $1.1645(.0936)^{\star *}$ \\
\hline Tigrean & Ref (1) & & & \\
\hline Affar & $-1.6573(.2552)$ & 0.000 & & \\
\hline Amara & $-.1623(.1525)$ & 0.287 & & \\
\hline Guragie & $-.4164(.1805)$ & 0.021 & & \\
\hline Somalie & $-1.1553(.2391)$ & 0.000 & & \\
\hline
\end{tabular}


Citation: Hailu TG (2016) A Multilevel Modeling Analysis of the Determinants and Cross-regional Variations of HIV Testing in Ethiopia: Ethiopian DHS 2011. J Biom Biostat 7: 277. doi:10.4172/2155-6180.1000277

Page 9 of 15

\begin{tabular}{|c|c|c|c|c|}
\hline Sidama & - $1.4286(.3133)$ & 0.000 & & \\
\hline Oromo & $-.6810(.1586)$ & 0.000 & & \\
\hline Nuwer & - 2.7991 (.3775) & 0.000 & & \\
\hline Welaiyta & $-.7378(.2432)$ & 0.002 & & \\
\hline Others & $-.7864(.1638)$ & 0.000 & & \\
\hline $\begin{array}{c}\text { Media } \\
\text { exposure }\end{array}$ & & & $.9884(.4417)^{\star \star}$ & $1.2488(.0993)^{\star *}$ \\
\hline Yes & $\operatorname{Ref}(0)$ & & & \\
\hline No & $.6828(.0476)$ & 0.000 & & \\
\hline Wealth Index & & & $.6942(.3130)^{*}$ & $.8146(.0710)^{\star}$ \\
\hline Poorest & $\operatorname{Ref}(0)$ & & & \\
\hline Poorer & $.3781(.0749)$ & 0.000 & & \\
\hline Middle & $.6245(.0775)$ & 0.000 & & \\
\hline Richer & $.9411(.0784)$ & 0.000 & & \\
\hline Richest & $1.7831(.0932)$ & 0.000 & & \\
\hline Marital status & & & $1.3189(.5865)$ & $1.6307(.1246)$ \\
\hline Not married & $\operatorname{Ref}(0)$ & & & \\
\hline Divorced & $.7211(.0890)$ & 0.000 & & \\
\hline Widowed & $.2136(.1081)$ & 0.048 & & \\
\hline Married & $.6551(.0459)$ & 0.000 & & \\
\hline $\begin{array}{l}\text { Relationship } \\
\text { with most } \\
\text { recent sex } \\
\text { partner }\end{array}$ & & & $.0003(.0001)^{\star *}$ & $.0556(.0051)^{\star \star}$ \\
\hline Living in partner & $\operatorname{Ref}(0)$ & & & \\
\hline Boy-girl friend & $.8288(.1749)$ & 0.000 & & \\
\hline Commercial & .0964 (.4040) & 0.811 & & \\
\hline Spouse & $-.4837(.1106)$ & 0.000 & & \\
\hline Other & $.0859(.3817)$ & 0.822 & & \\
\hline $\begin{array}{l}\text { Hear Family } \\
\text { planning on } \\
\text { Mass Media }\end{array}$ & & & $.8906(.3995)^{\star *}$ & $1.1701(.0942)^{\star *}$ \\
\hline No & $\operatorname{Ref}(0)$ & & & \\
\hline Yes & $.9312(.0450)$ & 0.000 & & \\
\hline $\begin{array}{l}\text { HIV related } \\
\text { knowledge }\end{array}$ & & & $.9899(.4421)^{\star *}$ & $1.2509(.0995)^{* *}$ \\
\hline Low & $\operatorname{Ref}(0)$ & & & \\
\hline High & $.4617(.0590)$ & 0.000 & & \\
\hline comprehensive & $.9047(.0604)$ & 0.000 & & \\
\hline $\begin{array}{l}\text { HIV related } \\
\text { stigma }\end{array}$ & & & $.8722(.3904)^{* *}$ & $1.1007(.0902)^{\star *}$ \\
\hline No stigma & $\operatorname{Ref}(0)$ & & & \\
\hline Low & $-.3436(.0545)$ & 0.000 & & \\
\hline Moderate & $-1.0143(.0567)$ & 0.000 & & \\
\hline High & $-1.4614(.1209)$ & 0.000 & & \\
\hline $\begin{array}{l}\text { HIV risky } \\
\text { behaviour }\end{array}$ & & & $1.1308(.5038)^{\star *}$ & $1.4054(.1091)^{* *}$ \\
\hline No risk & $\operatorname{Ref}(0)$ & & & \\
\hline Some risk & $-.2160(.0446)$ & 0.000 & & \\
\hline High & $-.5559(.0750)$ & 0.000 & & \\
\hline $\begin{array}{c}\text { Knowing Place } \\
\text { for HIV test }\end{array}$ & & & $.6684(.3015)^{\star *}$ & $.8009(.0730)^{* *}$ \\
\hline No & $\operatorname{Ref}(0)$ & & & \\
\hline Yes & $7.8255(.7087)$ & 0.000 & & \\
\hline
\end{tabular}

** Indicates significant value

Table 9: Parameters and standard errors of univariate multilevel model predicting the probability of ever been tested for HIV with random intercept and fixed slope among women, Ethiopia (S.Es are placed in parentheses).

found to be insignificant. Hence, the three level random intercept multilevel model is considered. Furthermore, this study has integrated the separate datasets of men and women into one profile to assess whether there is sexual variation with respect to HIV testing (Table 13).

\section{Discussion}

The main objective of this study was to provide an overall picture of the general patterns and determinants of HIV testing across regions in Ethiopia. In summary, this study showed that for both men and women, the probability of being tested for HIV was relatively higher

\begin{tabular}{|c|c|c|c|c|}
\hline \multirow[b]{3}{*}{ Model effect } & \multicolumn{4}{|c|}{ Multilevel model } \\
\hline & Men & & Women & \\
\hline & $\begin{array}{l}\text { Estimates } \\
\text { (SE):OR }\end{array}$ & $\begin{array}{l}\text { [95\% Conf. } \\
\text { Interval for OR] }\end{array}$ & $\begin{array}{c}\text { Estimates (SE): } \\
\text { OR }\end{array}$ & $\begin{array}{c}\text { [95\% } \\
\text { Conf. } \\
\text { Interval fo } \\
\text { OR] }\end{array}$ \\
\hline \multicolumn{5}{|l|}{ Fixed effect } \\
\hline Residence & $1.3714(0.1458)^{\star *}$ & {$[1.0856,1.6572]$} & $6.200(.8985)$ & $\begin{array}{l}{[4.6673} \\
8.2372]\end{array}$ \\
\hline \multicolumn{5}{|l|}{\begin{tabular}{|c|} 
Random \\
effect \\
Parameters
\end{tabular}} \\
\hline \multicolumn{5}{|l|}{ Region: } \\
\hline $\begin{array}{c}\text { Var } \\
\text { (residence) }\end{array}$ & $0.1187(0.0933)$ & {$[0.0253,0.5548]$} & $.0693(.0856)$ & $\begin{array}{l}{[.0061} \\
.7815]\end{array}$ \\
\hline $\operatorname{Var}$ (_cons) & $0.4137(0.1948)^{* *}$ & {$[0.1644,1.0412]$} & $.8138(.3705)^{\star *}$ & $\begin{array}{l}{[.3334,} \\
1.9865]\end{array}$ \\
\hline \multicolumn{5}{|l|}{ Cluster: } \\
\hline $\begin{array}{c}\text { Var } \\
\text { (residence) }\end{array}$ & $4.4 \mathrm{e}^{-18}\left(5.03 \mathrm{e}^{-10}\right)$ & 0 & $\begin{array}{l}2.76 \mathrm{e}-23( \\
1.09 \mathrm{e}-12)\end{array}$ & 0 \\
\hline $\operatorname{Var}$ (_cons) & $0.5574(0.0512)^{\star *}$ & {$[0.4655,0.6675]$} & $.9232(.0766)^{\star *}$ & $\begin{array}{l}{[.7845,} \\
1.0864]\end{array}$ \\
\hline$-2 \log \mathrm{L}$ & & & -9109.341 & \\
\hline Deviance & & & 18218.682 & \\
\hline $\begin{array}{l}\text { LR test } \\
\text { vs. logistic } \\
\text { regression: }\end{array}$ & \multicolumn{2}{|c|}{$\begin{array}{c}\text { chi2 } 2(2)=1789.56 \text { Prob }>\text { chi2 }= \\
0.0000\end{array}$} & \multicolumn{2}{|c|}{$\begin{array}{c}\text { chi2(4) }=2377.44 \text { Prob }> \\
\text { chi2 }=0.0000\end{array}$} \\
\hline \multicolumn{5}{|l|}{ Fixed effect } \\
\hline \multicolumn{5}{|l|}{ Wealth index } \\
\hline Poorer & $1.5623(.141)^{\star \star}$ & {$[1.308,1.865]$} & $1.4670(.1167)^{\star *}$ & $\begin{array}{l}{[1.2551} \\
1.7146]\end{array}$ \\
\hline Middle & $2.066(.2648)^{\star *}$ & {$[1.607,2.6562]$} & $1.9037(.1770)^{* *}$ & $\begin{array}{l}{[1.5864} \\
2.2844]\end{array}$ \\
\hline Richer & $3.2443(.559)^{\star *}$ & {$[2.314,4.5478]$} & $2.6368(.2890)^{* *}$ & $\begin{array}{l}{[2.1271} \\
3.2687]\end{array}$ \\
\hline Richest & $6.657(1.418)^{\star *}$ & {$[4.384,10.108]$} & $6.1330(.8233)^{* *}$ & $\begin{array}{l}{[4.7142,} \\
7.9789]\end{array}$ \\
\hline \multicolumn{5}{|l|}{ Region: } \\
\hline $\begin{array}{l}\text { Var (Wlth_ } \\
\text { Index) }\end{array}$ & $.0225(.0167)$ & {$[.0052, .0968]$} & $.0055(.0045)$ & $\begin{array}{l}{[.0011} \\
.0275]\end{array}$ \\
\hline $\operatorname{Var}$ (_cons) & $.7250(.4015)^{\star \star}$ & {$[.2448,2.1469]$} & $.8459(.3959)^{\star \star}$ & $\begin{array}{l}{[.3380,} \\
2.1169]\end{array}$ \\
\hline \multicolumn{5}{|l|}{ Cluster: } \\
\hline $\begin{array}{l}\text { Var (Wlth_ } \\
\text { Idex) }\end{array}$ & $\begin{array}{c}8.34 \mathrm{e}-19(7.09 \mathrm{e}- \\
11)\end{array}$ & 0 & $\begin{array}{c}1.26 \mathrm{e}-21 \\
(2.27 \mathrm{e}-12)\end{array}$ & 0 \\
\hline Var (_cons) & $.4766(.0463)^{\star *}$ & {$[.3939, .5767]$} & $.7983(.0702)$ & $\begin{array}{l}{[.6718,} \\
.9487]\end{array}$ \\
\hline Variance $\left(e_{i j k}\right)$ & $(3.1416)^{2} / 3=3.3$ & & 3.3 & \\
\hline$-2 \log L$ & -8517.327 & & -9767.64 & \\
\hline Deviance & 17034.654 & & 19535.28 & \\
\hline $\mathrm{N}$ & 14,110 & & 16,515 & \\
\hline $\begin{array}{l}\text { LR test } \\
\text { vs. logistic } \\
\text { regression: }\end{array}$ & \multicolumn{2}{|c|}{$\begin{array}{c}\operatorname{chi} 2(4)=1001.21 \text { Prob }>\text { chi } 2= \\
0.0000\end{array}$} & \multicolumn{2}{|c|}{$\begin{array}{c}\text { chi2 }(4)=1885.73 \text { Prob }> \\
\text { chi2 }=0.0000\end{array}$} \\
\hline
\end{tabular}

N.B: ** indicates that the estimates are significant such that estimates are two times higher than their respective standard errors.

Table 10: Parameters estimates and standard errors of a univariate random intercept and slope-only multilevel model predicting the probability of being tested for HIV (S.Es are placed in parentheses). 
Citation: Hailu TG (2016) A Multilevel Modeling Analysis of the Determinants and Cross-regional Variations of HIV Testing in Ethiopia: Ethiopian DHS 2011. J Biom Biostat 7: 277. doi:10.4172/2155-6180.1000277

Page 10 of 15

\begin{tabular}{|c|c|c|c|c|c|c|c|c|c|c|c|c|c|c|c|}
\hline Fixed effects & Model 1 & Model 2 & P-value & Model 3 & P-value & Model 4 & P-value & \multirow{2}{*}{ Richer } & & \multirow{2}{*}{$\begin{array}{l}2.2051 \\
(.1780)\end{array}$} & \multirow{2}{*}{0.000} & \multirow{2}{*}{$\begin{array}{l}1.6424 \\
(.1403)\end{array}$} & \multirow[t]{2}{*}{0.000} & \multirow{2}{*}{$\begin{array}{l}1.9092 \\
(.1561)\end{array}$} & \multirow{2}{*}{0.000} \\
\hline Age group & & & & & & & & & & & & & & & \\
\hline $15-19$ & & $\operatorname{Ref}(0)$ & & $\operatorname{Ref}(0)$ & & $\operatorname{Ref}(0)$ & & Richest & & $\begin{array}{l}3.0615 \\
(.3356)\end{array}$ & 0.000 & $\begin{array}{l}2.0368 \\
(.2324)\end{array}$ & 0.000 & $\begin{array}{l}2.6567 \\
(.2590)\end{array}$ & 0.000 \\
\hline $20-24$ & & $\begin{array}{l}2.0911 \\
(.1457)\end{array}$ & 0.000 & $\begin{array}{l}1.8611 \\
(.1352)\end{array}$ & 0.000 & $\begin{array}{l}1.9995 \\
(.1407)\end{array}$ & 0.000 & Marital status & & & & & & & \\
\hline $25-29$ & & $\begin{array}{l}2.5285 \\
(.2011)\end{array}$ & 0.000 & $\begin{array}{l}2.1879 \\
(.1815)\end{array}$ & 0.000 & $\begin{array}{l}2.4004 \\
(.1930)\end{array}$ & 0.000 & Not married & & $\operatorname{Ref}(0)$ & & $\operatorname{Ref}(0)$ & & Ref (0) & \\
\hline $30-34$ & & $\begin{array}{l}2.1644 \\
(.1999)\end{array}$ & 0.000 & $\begin{array}{l}1.9231 \\
(.1854)\end{array}$ & 0.000 & $\begin{array}{l}2.0439 \\
(.1905) \\
\end{array}$ & 0.000 & Divorced & & $\begin{array}{l}2.1139 \\
(.3096)\end{array}$ & 0.000 & $\begin{array}{l}2.0425 \\
(.3193)\end{array}$ & 0.000 & $\begin{array}{l}2.0896 \\
(.3109)\end{array}$ & 0.000 \\
\hline $35-39$ & & $\begin{array}{c}1.945 \\
(.1843) \\
\end{array}$ & 0.000 & $\begin{array}{l}1.7567 \\
(.1741)\end{array}$ & 0.000 & $\begin{array}{l}1.8900 \\
(.1810) \\
1.976\end{array}$ & 0.000 & Widowed & & $\begin{array}{l}2.0300 \\
(.5184)\end{array}$ & 0.006 & $\begin{array}{l}2.0326 \\
(.5574)\end{array}$ & 0.010 & $\begin{array}{l}1.9853 \\
(.5137)\end{array}$ & 0.008 \\
\hline $40-44$ & & $\begin{array}{l}1.5749 \\
(.1628)\end{array}$ & 0.000 & $\begin{array}{l}1.4278 \\
(.1547)\end{array}$ & 0.001 & $\begin{array}{l}1.4976 \\
(.1564) \\
\end{array}$ & 0.000 & Married & & $\begin{array}{l}1.7208 \\
(.1129)\end{array}$ & 0.000 & $\begin{array}{l}1.5849 \\
(.1079)\end{array}$ & 0.000 & \begin{tabular}{|l|}
1.6739 \\
$(.1107)$
\end{tabular} & 0.000 \\
\hline $45-49$ & & $\begin{array}{l}1.5983 \\
(.1749)\end{array}$ & 0.000 & $\begin{array}{l}1.4418 \\
(.1657)\end{array}$ & 0.001 & $\begin{array}{l}1.5249 \\
(.1686) \\
\end{array}$ & 0.000 & $\begin{array}{l}\text { HIV related } \\
\text { knowledge }\end{array}$ & & & & & & & \\
\hline $50-54$ & & $\begin{array}{l}1.4086 \\
(.1671)\end{array}$ & 0.004 & $\begin{array}{l}1.2783 \\
(.1593)\end{array}$ & 0.049 & $\begin{array}{l}1.3834 \\
(.1660)\end{array}$ & 0.007 & Low & & & & $\operatorname{Ref}(0)$ & & & \\
\hline $55-59$ & & $\begin{array}{l}1.0177 \\
(.1387)\end{array}$ & 0.897 & $\begin{array}{c}.9535 \\
(.1364)\end{array}$ & 0.739 & $\begin{array}{l}1.0138 \\
(.1398)\end{array}$ & 0.921 & High & & & & $\begin{array}{l}.8781 \\
(.0945)\end{array}$ & 0.227 & - & - \\
\hline $\begin{array}{l}\text { Place of } \\
\text { residence }\end{array}$ & & & & & & & & comprehensive & & & & $\begin{array}{l}1.0008 \\
(.1070)\end{array}$ & 0.993 & - & - \\
\hline Rural & & $\operatorname{Ref}(0)$ & & $\operatorname{Ref}(0)$ & & $\operatorname{Ref}(0)$ & & HIV related & & & & & & & \\
\hline Urban & & $\begin{array}{l}1.3667 \\
(.1667)\end{array}$ & 0.010 & $\begin{array}{l}1.0666 \\
(.1257)\end{array}$ & 0.584 & - & - & stigma & & & & & & & \\
\hline Education & & & & & & & & No stigma & & & & $\operatorname{Ref}(0)$ & & $\operatorname{Ref}(0)$ & \\
\hline level & & & & & & & & Low & & & & $\begin{array}{l}.8544 \\
(.0450)\end{array}$ & 0.003 & $\begin{array}{c}.8118 \\
(.0420)\end{array}$ & 0.000 \\
\hline No education & & 2.3060 & & 1.6590 & & 1.9224 & & Moderate & & & & $\begin{array}{l}.6972 \\
(.0426)\end{array}$ & 0.000 & $\begin{array}{c}.5630 \\
(.0329)\end{array}$ & 0.000 \\
\hline Primary & & $(.1270)$ & 0.000 & $(.1004)$ & 0.000 & $(.1092)$ & 0.000 & High & & & & 1.0813 & 0.753 & .5659 & 0.007 \\
\hline Secondary & & 3.8017 & 0.000 & 2.1964 & 0.000 & 2.8306 & 0.000 & Mign & & & & $(.2687)$ & 0.150 & & \\
\hline Higher & & $\begin{array}{l}(.31 / 3) \\
4.1499\end{array}$ & ( & $\begin{array}{l}(.1937) \\
2.3794\end{array}$ & תחת מ & \begin{tabular}{|l|}
$(.2416)$ \\
3.0359 \\
\end{tabular} & | & $\begin{array}{l}\text { HIV risky } \\
\text { behaviour }\end{array}$ & & & & & & & \\
\hline Higher & & $(.3892)$ & 0.000 & $(.2338)$ & 0.000 & $(.2903)$ & 0.000 & No risk & & & & $\operatorname{Ref}(0)$ & & & \\
\hline Religion & & & & & & & & Some risk & & & & 1.0347 & 0.542 & - & - \\
\hline Christian & & $\operatorname{Ref}(0)$ & & $\operatorname{Ref}(0)$ & & & & & & & & (.0578) & & - & - \\
\hline Muslim & & $\begin{array}{l}.9802 \\
(.0663)\end{array}$ & 0.768 & $\begin{array}{l}1.0238 \\
(.0741)\end{array}$ & 0.745 & - & - & High & & & & $\begin{array}{l}.9742 \\
(.1058)\end{array}$ & 0.810 & - & - \\
\hline Others & & $\begin{array}{c}.9044 \\
(.1449)\end{array}$ & 0.531 & $\begin{array}{l}1.0875 \\
(.1862)\end{array}$ & 0.624 & - & - & $\begin{array}{l}\text { Media } \\
\text { exposure }\end{array}$ & & & & & & & \\
\hline Ethnicity & & & & & & & & No & & & & $\operatorname{Ref}(0)$ & & & \\
\hline Tigrean & & $\operatorname{Ref}(0)$ & & $\operatorname{Ref}(0)$ & & $\operatorname{Ref}(0)$ & & Yes & & & & 1.3488 & 0.000 & 1.4892 & 0.000 \\
\hline Affar & & $\begin{array}{l}.6049 \\
(.1584)\end{array}$ & 0.055 & $\begin{array}{c}.6400 \\
(.1606)\end{array}$ & 0.075 & $\begin{array}{c}.6229 \\
(.1637)\end{array}$ & 0.072 & & & & & $(.1022)$ & 0.000 & $(.1059)$ & \\
\hline Amara & & $\begin{array}{l}.8298 \\
(.1280)\end{array}$ & 0.227 & $\begin{array}{c}.8639 \\
(.1283)\end{array}$ & 0.325 & $\begin{array}{c}.8803 \\
(.1367)\end{array}$ & 0.412 & $\begin{array}{l}\text { Heard Family } \\
\text { planning on }\end{array}$ & & & & & & & \\
\hline Guragie & & $\begin{array}{c}.6268 \\
(.1166)\end{array}$ & 0.012 & $\begin{array}{c}.6265 \\
(.1134)\end{array}$ & 0.010 & $\begin{array}{c}.6366 \\
(.1183)\end{array}$ & 0.015 & & & & & & & & \\
\hline Somolis & & .2835 & ( & .3334 & קח & .3264 & & No & & & & $\operatorname{Ref}(0)$ & & $\operatorname{Ref}(0)$ & \\
\hline Somalie & & $(.0679)$ & 0.000 & $(.0756)$ & 0.000 & $(.0780)$ & 0.000 & Yes & & & & $\begin{array}{l}1.4495 \\
(0763)\end{array}$ & 0.000 & $\begin{array}{l}1.5926 \\
(.0799)\end{array}$ & 0.000 \\
\hline Sidama & & $\begin{array}{l}.4513 \\
(.1252)\end{array}$ & 0.004 & $\begin{array}{c}.5438 \\
(.1442)\end{array}$ & 0.022 & $\begin{array}{c}.5038 \\
(.1405)\end{array}$ & 0.014 & Knowing & & & & & & & \\
\hline Oromo & & $\begin{array}{c}.6279 \\
(.1020)\end{array}$ & 0.004 & $\begin{array}{c}.6850 \\
(.1078)\end{array}$ & 0.016 & $\begin{array}{c}.6662 \\
(.1085)\end{array}$ & 0.013 & $\begin{array}{l}\text { Place for HIV } \\
\text { test }\end{array}$ & & & & & & & \\
\hline Numer & & .3297 & 0000 & .4718 & 0,014 & .3802 & (2002 & No & & & & & & & \\
\hline INuwer & & $(.1033)$ & & $(.1448)$ & & $(.1204)$ & & Yes & & & & $1.72 \mathrm{e}+08$ & 0.960 & - & _- \\
\hline Welaiyta & & .7456 & 0.216 & .8388 & 0.449 & .8541 & 0.510 & & & & & $(6.43 e+10)$ & & & \\
\hline Wvelalyta & & $(.1769)$ & 0.210 & $(.1947)$ & 0.449 & $(.2041)$ & 0.510 & Random & Model 1 & Model 2 & & Model 3 & & Model 4 & \\
\hline Others & & .5625 & ( & .6849 & 0017 & .6443 & ( & effects & & & & & & & \\
\hline Others & & $(.0918)$ & 0.000 & $(.1081)$ & 0.017 & $(.1058)$ & 0.007 & Var (Region) & $\begin{array}{c}.4193 \\
(.1917)^{\star \star}\end{array}$ & $\begin{array}{c}.1440 \\
(.0733)^{\star \star}\end{array}$ & & $\begin{array}{c}.0742 \\
(.0406)^{\star \star}\end{array}$ & & $\begin{array}{c}.1615 \\
(.0801)^{\star \star}\end{array}$ & \\
\hline Wealth Index & & & & & & $\operatorname{Ref}(0)$ & & Var (Cluster) & $\begin{array}{c}.8591 \\
(.0718)^{\star \star}\end{array}$ & $\begin{array}{c}.5236 \\
(.0498)^{\star \star}\end{array}$ & & $\begin{array}{c}.4126 \\
(.0435)^{\star \star}\end{array}$ & & $\begin{array}{c}.5191 \\
(.0497)^{\star \star}\end{array}$ & \\
\hline Poorest & & $\operatorname{Ref}(0)$ & & $\operatorname{Ref}(0)$ & & Ret (U) & & & & & & & & & \\
\hline Poorer & & $\begin{array}{l}1.4007 \\
(.1079)\end{array}$ & 0.000 & $\begin{array}{l}1.2531 \\
(.1029)\end{array}$ & 0.006 & $\begin{array}{l}1.3360 \\
(.1043)\end{array}$ & 0.000 & Var (Residual) & 3.27 & 3.27 & & 3.27 & & 3.27 & \\
\hline Middle & & $\begin{array}{l}1.6820 \\
(.1325)\end{array}$ & 0.000 & $\begin{array}{l}1.4155 \\
(.1184)\end{array}$ & 0.000 & $\begin{array}{l}1.5302 \\
(.1222)\end{array}$ & 0.000 & $\begin{array}{l}\text { Model Fit } \\
\text { Statistics }\end{array}$ & Model 1 & Model 2 & & Model 3 & & Model 4 & \\
\hline
\end{tabular}


Citation: Hailu TG (2016) A Multilevel Modeling Analysis of the Determinants and Cross-regional Variations of HIV Testing in Ethiopia: Ethiopian DHS 2011. J Biom Biostat 7: 277. doi:10.4172/2155-6180.1000277

Page 11 of 15

\begin{tabular}{|l|l|l|l|l|l|l|l|}
\hline Deviance & 17488.88 & 16114.77 & & 14440.73 & & 15816.75 & \\
\hline AIC & 17454.89 & 16180.77 & & 14526.74 & & 15886.76 & \\
\hline BIC & 17477.55 & 16430.07 & & 14851.59 & & 16151.17 & \\
\hline
\end{tabular}

N.B:

Model 1: Represents random intercept model i.e. an empty model

Model 2: A multilevel multiple logistic model that consists socio-demographic and economic variables

Model 3: A multilevel logistic model included both socioeconomic characteristics and HIV related knowledge, stigma, risky social behaviour, media exposure, heard family planning and knowing place where to get test for HIV.

Model 4: The final multilevel logistic model with significant predictors associated with HIV testing

Table 11: Parameters and standard errors of multiple multilevel model predicting the probability of ever been tested for HIV with random intercept and fixed slope among men, Ethiopia (S.E.s are placed in parentheses).

\begin{tabular}{|c|c|c|c|c|c|c|c|}
\hline Fixed effects & Model 1 & Model 2 & P-value & Model 3 & P-value & Model 4 & P-value \\
\hline \multicolumn{8}{|l|}{ Age group } \\
\hline $15-19$ & & $\operatorname{Ref}(0)$ & & $\operatorname{Ref}(0)$ & & $\operatorname{Ref}(0)$ & \\
\hline $20-24$ & & $\begin{array}{l}1.9262 \\
(.1285)\end{array}$ & 0.000 & $\begin{array}{l}2.0146 \\
(.1462)\end{array}$ & 0.000 & $\begin{array}{l}1.9916 \\
(.1443)\end{array}$ & 0.000 \\
\hline $25-29$ & & $\begin{array}{l}1.8252 \\
(.1322)\end{array}$ & 0.000 & $\begin{array}{l}1.7903 \\
(.1406) \\
\end{array}$ & 0.000 & $\begin{array}{l}1.7688 \\
(.1385)\end{array}$ & 0.000 \\
\hline $30-34$ & & $\begin{array}{l}1.6209 \\
(.1334)\end{array}$ & 0.000 & $\begin{array}{l}1.6409 \\
(.1474)\end{array}$ & 0.000 & $\begin{array}{l}1.6165 \\
(.1448)\end{array}$ & 0.000 \\
\hline $35-39$ & & $\begin{array}{l}1.3888 \\
(.1167)\end{array}$ & 0.000 & $\begin{array}{l}1.4086 \\
(.1298)\end{array}$ & 0.000 & $\begin{array}{l}1.3836 \\
(.1270)\end{array}$ & 0.000 \\
\hline $40-44$ & & $\begin{array}{l}1.1360 \\
(.1085)\end{array}$ & 0.182 & $\begin{array}{l}1.0791 \\
(.1127)\end{array}$ & 0.466 & $\begin{array}{l}1.0593 \\
(.1103)\end{array}$ & 0.580 \\
\hline $45-49$ & & $\begin{array}{c}.8529 \\
(.0879)\end{array}$ & 0.123 & $\begin{array}{c}.8576 \\
(.0964)\end{array}$ & 0.172 & $\begin{array}{c}.8398 \\
(.0941)\end{array}$ & 0.120 \\
\hline $50-54$ & & - & - & - & - & - & - \\
\hline $55-59$ & & - & - & - & - & - & - \\
\hline \multicolumn{8}{|l|}{$\begin{array}{l}\text { Place of } \\
\text { residence }\end{array}$} \\
\hline Rural & & $\operatorname{Ref}(0)$ & & $\operatorname{Ref}(0)$ & & $\operatorname{Ref}(0)$ & \\
\hline Urban & & $\begin{array}{l}2.3337 \\
(.3073)\end{array}$ & 0.000 & $\begin{array}{l}1.4972 \\
(.1875) \\
\end{array}$ & 0.001 & $\begin{array}{l}1.4830 \\
(.1857)\end{array}$ & 0.002 \\
\hline \multicolumn{8}{|l|}{$\begin{array}{l}\text { Education } \\
\text { level }\end{array}$} \\
\hline No education & & $\operatorname{Ref}(0)$ & & $\operatorname{Ref}(0)$ & & $\operatorname{Ref}(0)$ & \\
\hline Primary & & $\begin{array}{l}2.3076 \\
(.1208)\end{array}$ & 0.000 & $\begin{array}{l}1.6785 \\
(.1013)\end{array}$ & 0.000 & $\begin{array}{l}1.6854 \\
(.1004)\end{array}$ & 0.000 \\
\hline Secondary & & $\begin{array}{l}3.7547 \\
(.3261)\end{array}$ & 0.000 & $\begin{array}{l}2.0280 \\
(.1893)\end{array}$ & 0.000 & $\begin{array}{l}2.0401 \\
(.1880)\end{array}$ & 0.000 \\
\hline Higher & & $\begin{array}{l}5.0011 \\
(.5296)\end{array}$ & 0.000 & $\begin{array}{l}2.6474 \\
(.2955)\end{array}$ & 0.000 & $\begin{array}{l}2.6364 \\
(.2913)\end{array}$ & 0.000 \\
\hline \multicolumn{8}{|l|}{ Religion } \\
\hline Christian & & $\operatorname{Ref}(0)$ & & $\operatorname{Ref}(0)$ & & $\operatorname{Ref}(0)$ & \\
\hline Muslim & & $\begin{array}{l}1.0461 \\
(.0736)\end{array}$ & 0.522 & $\begin{array}{l}1.0516 \\
(.0798)\end{array}$ & 0.508 & - & - \\
\hline Others & & $\begin{array}{c}.4702 \\
(.1077)\end{array}$ & 0.001 & $\begin{array}{c}.5127 \\
(.1256)\end{array}$ & 0.006 & - & - \\
\hline \multicolumn{8}{|l|}{ Ethnicity } \\
\hline Tigrean & & $\operatorname{Ref}(0)$ & & $\operatorname{Ref}(0)$ & & $\operatorname{Ref}(0)$ & \\
\hline Affar & & $\begin{array}{c}.3420 \\
(.0888)\end{array}$ & 0.000 & $\begin{array}{c}.4594 \\
(.1266)\end{array}$ & 0.005 & $\begin{array}{c}.4865 \\
(.1329)\end{array}$ & 0.008 \\
\hline Amara & & $\begin{array}{c}.7736 \\
(.1226)\end{array}$ & 0.105 & $\begin{array}{c}.7178 \\
(.1165)\end{array}$ & 0.041 & $\begin{array}{l}.7225( \\
.1173)\end{array}$ & 0.045 \\
\hline Guragie & & $\begin{array}{c}.6649 \\
(.1250)\end{array}$ & 0.030 & $\begin{array}{c}.5761 \\
(.1097)\end{array}$ & 0.004 & $\begin{array}{l}.5986( \\
.1132)\end{array}$ & 0.007 \\
\hline Somalie & & $\begin{array}{c}.3192 \\
(.0798)\end{array}$ & 0.000 & $\begin{array}{c}.3453 \\
(.0899)\end{array}$ & 0.000 & $\begin{array}{l}.3670( \\
.0945)\end{array}$ & 0.000 \\
\hline Sidama & & $\begin{array}{c}.2741 \\
(.0817)\end{array}$ & 0.000 & $\begin{array}{c}.3409 \\
(.0999)\end{array}$ & 0.000 & $\begin{array}{l}3522( \\
.1033)\end{array}$ & 0.000 \\
\hline Oromo & & $\begin{array}{c}.5457 \\
(.0902)\end{array}$ & 0.000 & $\begin{array}{c}.5796 \\
(.0982)\end{array}$ & 0.001 & $\begin{array}{l}.5964( \\
.1006)\end{array}$ & 0.002 \\
\hline
\end{tabular}

\begin{tabular}{|c|c|c|c|c|c|c|c|}
\hline Nuwer & & \begin{tabular}{|c|}
.1135 \\
$(.0400)$ \\
\end{tabular} & 0.000 & $\begin{array}{c}.2593 \\
(.0899)\end{array}$ & 0.000 & $\begin{array}{l}.2601( \\
.0903)\end{array}$ & 0.000 \\
\hline Welaiyta & & \begin{tabular}{|c|}
.4996 \\
$(.1233)$ \\
\end{tabular} & 0.005 & $\begin{array}{c}.4630 \\
(.1164)\end{array}$ & 0.002 & $\begin{array}{l}.4754( \\
.1195)\end{array}$ & 0.003 \\
\hline Others & & \begin{tabular}{|c|}
.4873 \\
$(.0821)$ \\
\end{tabular} & 0.000 & $\begin{array}{c}.5480 \\
(.0943)\end{array}$ & 0.000 & $\begin{array}{l}.5520( \\
.0948)\end{array}$ & 0.001 \\
\hline \multicolumn{8}{|l|}{ Wealth Index } \\
\hline Poorest & & $\operatorname{Ref}(0)$ & & $\operatorname{Ref}(0)$ & & $\operatorname{Ref}(0)$ & \\
\hline Poorer & & $\begin{array}{l}1.3315 \\
(.1020) \\
\end{array}$ & 0.000 & $\begin{array}{l}1.2509 \\
(.1085)\end{array}$ & 0.010 & $\begin{array}{c}1.2694( \\
.1097)\end{array}$ & 0.006 \\
\hline Middle & & $\begin{array}{l}1.6265 \\
(.1291) \\
\end{array}$ & 0.000 & $\begin{array}{l}1.4386 \\
(.1286)\end{array}$ & 0.000 & $\begin{array}{l}1.4736 \\
(.1310)\end{array}$ & 0.000 \\
\hline Richer & & $\begin{array}{l}2.0081 \\
(.1629)\end{array}$ & 0.000 & $\begin{array}{l}1.5903 \\
(.1449)\end{array}$ & 0.000 & $\begin{array}{c}1.6326( \\
.1476)\end{array}$ & 0.000 \\
\hline Richest & & $\begin{array}{l}2.6473 \\
(.2874)\end{array}$ & 0.000 & $\begin{array}{l}1.7771 \\
(.2136)\end{array}$ & 0.000 & $\begin{array}{c}1.8394( \\
.2193)\end{array}$ & 0.000 \\
\hline \multicolumn{8}{|l|}{ Marital status } \\
\hline Not married & & $\operatorname{Ref}(0)$ & & $\operatorname{Ref}(0)$ & & $\operatorname{Ref}(0)$ & \\
\hline Divorced & & $\begin{array}{l}2.6632 \\
(.2622) \\
\end{array}$ & 0.000 & $\begin{array}{l}2.6329 \\
(.2853)\end{array}$ & 0.000 & $\begin{array}{l}2.6293 \\
(.2845)\end{array}$ & 0.000 \\
\hline Widowed & & $\begin{array}{l}2.2875 \\
(.2835) \\
\end{array}$ & 0.000 & $\begin{array}{l}2.1413 \\
(.2899)\end{array}$ & 0.000 & $\begin{array}{l}2.1297 \\
(.2883)\end{array}$ & 0.000 \\
\hline Married & & \begin{tabular}{l|}
2.4906 \\
$(.1544)$ \\
\end{tabular} & 0.000 & $\begin{array}{l}2.4681 \\
(.1637)\end{array}$ & 0.000 & $\begin{array}{l}2.4700 \\
(.1635)\end{array}$ & 0.000 \\
\hline \multicolumn{8}{|l|}{$\begin{array}{l}\text { HIV related } \\
\text { knowledge }\end{array}$} \\
\hline Low & & & & $\operatorname{Ref}(0)$ & & $\operatorname{Ref}(0)$ & \\
\hline High & & & & $\begin{array}{c}.9015 \\
(.0652)\end{array}$ & 0.152 & - & - \\
\hline comprehensive & & & & $\begin{array}{c}.8867 \\
(.0654)\end{array}$ & 0.103 & - & - \\
\hline \multicolumn{8}{|l|}{$\begin{array}{l}\text { HIV related } \\
\text { stigma }\end{array}$} \\
\hline No stigma & & & & $\operatorname{Ref}(0)$ & & $\operatorname{Ref}(0)$ & \\
\hline Low & & & & $\begin{array}{c}.9115 \\
(.0552)\end{array}$ & 0.127 & $\begin{array}{c}.9144 \\
(.0553)\end{array}$ & 0.139 \\
\hline Moderate & & & & $\begin{array}{c}.6176 \\
(.0407)\end{array}$ & 0.000 & $\begin{array}{c}.6176 \\
(.0403)\end{array}$ & 0.000 \\
\hline High & & & & $\begin{array}{c}.6325 \\
(.0937)\end{array}$ & 0.002 & $\begin{array}{c}.6420 \\
(.0943)\end{array}$ & 0.003 \\
\hline \multicolumn{8}{|l|}{$\begin{array}{l}\text { HIV risky } \\
\text { behaviour }\end{array}$} \\
\hline No risk & & & & $\operatorname{Ref}(0)$ & & & \\
\hline Some risk & & & & $\begin{array}{c}.9203 \\
(.0489)\end{array}$ & 0.118 & - & - \\
\hline High & & & & $\begin{array}{c}.8542 \\
(.0762)\end{array}$ & 0.078 & - & - \\
\hline \multicolumn{8}{|l|}{$\begin{array}{l}\text { Media } \\
\text { exposure }\end{array}$} \\
\hline No & & & & $\operatorname{Ref}(0)$ & & $\operatorname{Ref}(0)$ & \\
\hline Yes & & & & $\begin{array}{l}1.0693 \\
(.0651)\end{array}$ & 0.271 & $\begin{array}{l}1.4705 \\
(.0782)\end{array}$ & 0.000 \\
\hline \multicolumn{8}{|l|}{$\begin{array}{l}\text { Heard Family } \\
\text { planning on } \\
\text { Mass Media }\end{array}$} \\
\hline No & & & & $\operatorname{Ref}(0)$ & & $\operatorname{Ref}(0)$ & \\
\hline Yes & & & & $\begin{array}{l}1.4370 \\
(.0807)\end{array}$ & 0.000 & $\begin{array}{l}1.4705 \\
(.0782)\end{array}$ & 0.000 \\
\hline \multicolumn{8}{|l|}{$\begin{array}{l}\text { Knowing } \\
\text { Place for HIV } \\
\text { test }\end{array}$} \\
\hline No & & & & $\operatorname{Ref}(0)$ & & $\operatorname{Ref}(0)$ & \\
\hline Yes & & & & $\begin{array}{c}1891.14 \\
(1340)\end{array}$ & 0.000 & $\begin{array}{c}1875.2 \\
(1328.6)\end{array}$ & 0.000 \\
\hline $\begin{array}{l}\text { Random } \\
\text { effects }\end{array}$ & Model 1 & Model 2 & & Model 3 & & Model 4 & \\
\hline Region & $\begin{array}{c}1.1608 \\
(.5173)^{\star \star}\end{array}$ & $\begin{array}{c}.7241 \\
(.0636)^{\star *}\end{array}$ & & $\begin{array}{c}.2679 \\
(.1354)^{\star *}\end{array}$ & & $\begin{array}{c}.2733 \\
(.1373)^{\star *}\end{array}$ & \\
\hline
\end{tabular}


Citation: Hailu TG (2016) A Multilevel Modeling Analysis of the Determinants and Cross-regional Variations of HIV Testing in Ethiopia: Ethiopian DHS 2011. J Biom Biostat 7: 277. doi:10.4172/2155-6180.1000277

Page 12 of 15

\begin{tabular}{|l|c|c|c|c|c|c|c|}
\hline Cluster & $\begin{array}{c}1.4636 \\
(.1127)^{\star *}\end{array}$ & $\begin{array}{c}.7241 \\
(.0636)^{\star *}\end{array}$ & & $\begin{array}{c}.4678 \\
(.0505)^{\star *}\end{array}$ & $\begin{array}{c}.4764 \\
(.0510)^{\star *}\end{array}$ & \\
\hline Residual & 3.27 & 3.27 & & 3.27 & & 3.27 & \\
\hline $\begin{array}{l}\text { Model Fit } \\
\text { Statistics }\end{array}$ & Model 1 & Model 2 & & Model 3 & & Model 4 & \\
\hline Deviance & 18420.45 & 18085.76 & & 14948.03 & & 13612.16 & \\
\hline AIC & 18426.45 & 18096.89 & & 14959.04 & 13680.17 & \\
\hline BIC & 18449.59 & 18343.68 & & 15304.48 & & 13942.38 & \\
\hline
\end{tabular}

NB:

Model 1: Represents random intercept model i.e. an empty model

Model 2: A multilevel multiple logistic model that consists socio-demographic and economic variables

Model 3: A multilevel logistic model included both socioeconomic characteristics and HIV related knowledge, stigma, risky social behaviour, media exposure, heard family planning and knowing place where to get test for HIV.

Model 4: The final multilevel logistic model with significant predictors associated with HIV testing

Table 12: Parameters and standard errors of multiple multilevel model predicting the probability of ever been tested for HIV with random intercept and fixed slope among women, Ethiopia (S.E.s are placed in parentheses).

\begin{tabular}{|c|c|c|c|}
\hline Fixed effects & Model 1 & Model 2 & P-value \\
\hline Intercept & $.4150(.0098)^{\star \star}$ & $.1640(.0222)$ & 0.000 \\
\hline \multicolumn{4}{|l|}{ Sex } \\
\hline Female & & $\operatorname{Ref}(0)$ & \\
\hline Male & & $.6762(.0226)$ & 0.000 \\
\hline \multicolumn{4}{|l|}{ Age group } \\
\hline $15-19$ & & $\operatorname{Ref}(0)$ & \\
\hline $20-24$ & & $1.9163(.0957)$ & 0.000 \\
\hline $25-29$ & & $1.9474(.1082)$ & 0.000 \\
\hline $30-34$ & & $1.6596(.1058)$ & 0.000 \\
\hline $35-39$ & & $1.4787(.0970)$ & 0.000 \\
\hline $40-44$ & & $1.1811(.0861)$ & 0.022 \\
\hline $45-49$ & & $1.0536(.0822)$ & 0.503 \\
\hline $50-54$ & & $1.0403(.1127)$ & 0.715 \\
\hline $55-59$ & & $.7918(.1015)$ & 0.069 \\
\hline \multicolumn{4}{|c|}{ Place of residence } \\
\hline \multicolumn{4}{|l|}{ Rural } \\
\hline Urban & & $1.2886(.1234)$ & 0.008 \\
\hline \multicolumn{4}{|l|}{ Education level } \\
\hline \multicolumn{4}{|l|}{ No education } \\
\hline Primary & & $1.6423(.0676)$ & 0.000 \\
\hline Secondary & & $2.0853(.1289)$ & 0.000 \\
\hline Higher & & $2.4134(.1701)$ & 0.000 \\
\hline \multicolumn{4}{|l|}{ Ethnicity } \\
\hline \multicolumn{4}{|l|}{ Tigrean } \\
\hline Affar & & $.5723(.1092)$ & 0.003 \\
\hline Amara & & $.7885(.0878)$ & 0.033 \\
\hline Guragie & & $.6143(.0808)$ & 0.000 \\
\hline Somalie & & $.3474(.0607)$ & 0.000 \\
\hline Sidama & & $.4651(.1000)$ & 0.000 \\
\hline Oromo & & $.6587(.0767)$ & 0.000 \\
\hline Nuwer & & $.3519(.0883)$ & 0.000 \\
\hline Welaiyta & & $.6709(.1185)$ & 0.024 \\
\hline Others & & $.6229(.0740)$ & 0.000 \\
\hline \multicolumn{4}{|l|}{ Wealth Index } \\
\hline \multicolumn{4}{|l|}{ Poorest } \\
\hline Poorer & & $1.2380(.0734)$ & 0.000 \\
\hline Middle & & $1.4117(.0861)$ & 0.000 \\
\hline Richer & & $1.6025(.1002)$ & 0.000 \\
\hline Richest & & $1.8780(.1567)$ & 0.000 \\
\hline \multicolumn{4}{|l|}{ Marital status } \\
\hline Not married & & $\operatorname{Ref}(0)$ & \\
\hline
\end{tabular}

\begin{tabular}{|c|c|c|c|}
\hline Divorced & & $2.2773(.1957)$ & 0.000 \\
\hline Widowed & & $1.8723(.2163)$ & 0.000 \\
\hline Married & & $2.0262(.0925)$ & 0.000 \\
\hline \multicolumn{4}{|l|}{$\begin{array}{l}\text { HIV related } \\
\text { stigma }\end{array}$} \\
\hline No stigma & & $\operatorname{Ref}(0)$ & \\
\hline Low & & $.8972(.0348)$ & 0.005 \\
\hline Moderate & & $.6791(.0294)$ & 0.000 \\
\hline High & & $.7574(.0917)$ & 0.022 \\
\hline \multicolumn{4}{|l|}{ Media exposure } \\
\hline No & & $\operatorname{Ref}(0)$ & \\
\hline Yes & & $1.1867(.0542)$ & 0.000 \\
\hline \multicolumn{4}{|l|}{$\begin{array}{c}\text { Heard Family } \\
\text { planning on Mass } \\
\text { Media }\end{array}$} \\
\hline \multicolumn{4}{|l|}{ No } \\
\hline Yes & & $1.4417(.0540)$ & 0.000 \\
\hline \multicolumn{4}{|l|}{$\begin{array}{c}\text { Knowing Place for } \\
\text { HIV test }\end{array}$} \\
\hline No & & Ref $(0)$ & \\
\hline Yes & & $2302.016(1629.32)$ & 0.000 \\
\hline Random effects & Model 1 & Model 2 & \\
\hline Region & $\begin{array}{c}.7400 \\
(.3292)^{\star *}\end{array}$ & $\begin{array}{c}.1296 \\
(.0646)^{\star *}\end{array}$ & \\
\hline Cluster & $\begin{array}{c}1.0638 \\
(.0749)^{\star *}\end{array}$ & $\begin{array}{c}.3732 \\
(.0328)^{\star *}\end{array}$ & \\
\hline Residual & 3.27 & 3.27 & \\
\hline $\begin{array}{l}\text { Model Fit } \\
\text { Statistics }\end{array}$ & Model 1 & Model 3 & \\
\hline Deviance & 35670.31 & 28144.07 & \\
\hline $\mathrm{AIC}$ & 35676.32 & 28220.08 & \\
\hline $\mathrm{BIC}$ & 35701.31 & 28536.61 & \\
\hline
\end{tabular}

Table 13: Parameters and standard errors of multiple multilevel model predicting the probability of ever been tested for HIV with random intercept and fixed slope among adults (both men and women together), Ethiopia (S.E.s are placed in parentheses).

among wealthier households, higher educated people, those of age categories of 20 to 34 years old, people who have no stigmatizing attitude towards HIV infected person and who have heard about family planning in Ethiopia.

The final multilevel model (Table 12) demonstrated that participants who were in the age categories of 20 to 34 years old (of both men and women) were more likely to have ever been tested for HIV than those who belong to a reference age category (15-19 years). This showed that those of men and/or women belonging to different age categories of same cluster nested with in a region might differ on utilizing the HIV testing significantly across the region. A nationwide study conducted in Ethiopia has also revealed that those people who were in the age category of 15 to 40 are the most affected group by HIV/ AIDS which has the highest prevalence of HIV infection [1]. This study has also noted that there is a positive association between HIV testing and age categories of participants (20 to 29). This association might be justified due to the better awareness in which they might obtained through school, public gatherings, clubs, organizations and using other means of mass media [26].

This study has also showed that the rate of HIV testing was increasing with an increment in educational level. The odds of women who were belonging to higher educational level were more than twice $(\mathrm{OR}=2.64)$ more likely to have ever been tested for HIV compared to odds of women who were belonging to no education category while other predictors are holding constant. A study conducted in Kenya 
showed that education was positively associated with HIV testing [27]. Similarly, this study has also revealed that those who were with higher educational level were more likely to be tested for HIV.

This study demonstrated that the probability of ever being tested for HIV showed an increased pattern with increasing wealth index among adults of both men and women in Ethiopia. This indicates that those of individuals who were belonging to the same cluster nested in a region of belonging to different wealth index of the household have a positive correlation with HIV testing though not perfectly linear. Auburn Larose et al stated that the association between HIV testing and wealth status is generally positive though not strictly linear [28]. This might be related to the fact that the differences in wealth status which was observed among individuals in Ethiopia could be a barrier on creating awareness through mass media, accessing education, preventing from risky sexual behaviors as a result this could lead to poor HIV testing practice.

Furthermore, this study demonstrated that those who had higher wealth index of same clusters nested within a region were more likely to get tested for HIV. A study conducted in Kenya has also showed that a significant difference of HIV testing practice among individuals who were belonging to the poorer, middle, richer and richest wealth categories and had a greater probability of getting to be tested for HIV than the individuals who were in the poorest wealth category, the reference group [27]. This might reflect that the wealthier individuals had a wider opportunity to access education and mass media which have direct impact on HIV testing utilization than the poorest and this agrees with this study. It had been also stated that the inequalities in socio-economic position result in unequal health outcomes in general [29]. Similarly, the variation observed on being tested for HIV leads to inequality in access to prevention and treatment of HIV/AIDS.

In this study, it has been also shown that having HIV related stigma was also negatively associated with ever being tested for HIV. This indicates that those of individuals who were belonging to the same cluster nested in a region of belonging to different stigmatizing index of the household have a negative correlation with HIV testing practice. A study based on EDHS 2005 revealed that having stigmatizing attitudes toward people living with HIV/AIDS person was found to be negatively associated with HIV testing utilization in both urban and rural areas [26]. This stigmatizing attitude observed within the community could let the individuals not to be tested in a timely manner even though people are at substantial risk for HIV infection. Moreover, this could justify that the odds of those individuals who came from community/ cluster with high level of stigmatization constituted the lesser proportion of being tested for HIV than those individuals who came from a community/cluster with no stigmatization towards to a person living with HIV/AIDS while other predictors are keeping constant.

This study has also indicated that marital status was significantly associated with ever being tested for HIV. This is consistent with a study conducted in South Africa and showed that those married individuals were more likely to have ever been tested for HIV than those single once [30]. Furthermore, another study had been conducted in four south Indian states; indicated that marital status was confirmed as an important indicator of HIV risk [31]. The study indicates that married female sexual workers (FSW) who resided with their husbands started sex work relatively later in life and had a lower sex client volume. FSW who were widowed and divorced also tended to start sex work relatively later in life (mostly after separation from their husbands), but depended exclusively on sex work for income. It further indicates that unmarried female sexual workers, on the other hand, were younger and reported a higher client volume. This result could reflect that those un-married FSW who had a history of risky sexual behavior (having sexual activity with higher client volume) might have perceived them as being at risk of HIV infection and thus hinders them for HIV testing due to the possible psychosocial factors such as fear of HIV/AIDS related stigma and discrimination and discrediting from their community. Moreover, the variability in the current marital status of adults across the regions in Ethiopia could represent the different patterns on HIV testing and has an important influence on HIV testing program implications.

This study has also revealed that having knowledge on family planning was positively associated with ever being tested for HIV. This is consistent with the findings of a systematic review which found that behaviors that might lead to unintended pregnancies can also be a risk factor for HIV infection [32,33]. Therefore, having knowledge on family planning may provide a wider opportunity to be tested for HIV.

This study also demonstrated that ethnicity was significantly associated with HIV testing among both men and women. Individuals from other ethnic group in Ethiopia (non-Tigreans) were less likely (i.e. OR $<1$ for all other ethnics) to have ever been tested for HIV than the Tigreans of Tigray region. There was borderline significant (P-value $=0.045)$ difference on HIV testing among women belonging to the Tigreans and Amara ethnic groups of Ethiopia (Table 11 and 12). This study has also showed that the Nuwer ethnic group (Gambella region) was less likely to have ever been tested for HIV compared to any other ethnic groups among both men and women in Ethiopia and yet in Gambella region it has been reported that the prevalence of HIV is higher $(6.5 \%)$ than that of the national rate (1.5\%) [12]. It has been reported that the proportion of black students and had been tested is higher (24\%) than Hispanic students (12\%) and white students (11\%) [9]. Moreover, Denison JA et al conducted a study in Nairobi urban informal settlements and noted that ethnicity was associated with ever being tested for HIV. The study has also revealed that the Luhya ethnic group was less likely to have had either client initiative testing and provider initiated testing and counseling compared to Kikuyu. These differences might be attributed to the cultural differences, HIV related knowledge, exposure to mass media, access to health services and other risky sexual behaviors that place them at risk to ever being tested for HIV. However, this study recommends that it is highly important that future ethnographic research should investigate this observation.

Furthermore, this study has integrated the separate datasets of men and women to assess whether there is sexual variation with respect to HIV testing or not in Ethiopia. This study hence also revealed that men were less likely to have ever been tested for HIV than women. The odds of men who had ever being tested for HIV (OR=0.67) were 33\% less likely than women while other predictors are holding constant. This is similar to a study conducted in Nairobi which showed that sex differentials were confirmed and women were more likely to have had testing for HIV compared to men. The apparently wider gap observed on HIV testing between women and men in Ethiopia might be due to the increased testing services among women in PMTCT programs. Another study also conducted in USA has also showed that the rate of HIV testing is varied by sex [9].

It has been also reported that women are at a greater risk of heterosexual transmission of HIV. This is due to the fact that biologically women are twice more likely to become infected with HIV through unprotected heterosexual intercourse than men. This result could reflect that those people who had a history of risky sexual behavior might have perceived themselves as being at risk of HIV infection and thus be motivated to be tested for HIV. The major limitation of 
this study is that its principal data source is a cross-sectional survey; potentially affected by recall bias in case the test was offered long time ago. However, it is also a large representative population-based sample with high survey completion rates and very little missing data which allowed for greater generalization of these findings are strong side of the study.

\section{Conclusions and Recommendations}

This study used multilevel modeling analysis on HIV testing dataset and the results showed that there was significant variation of HIV testing across clusters and to a lesser extent across regions among both men and women in Ethiopia. About 4.07\% (6.68\%) of the total variation on ever being tested for HIV was attributable to region-level factors and $17.27 \%$ (18.45\%) was attributable to cluster level factors among men (women) respectively. This indicates that random effects are useful for modeling intra-cluster correlation; that is, observations in the same cluster were correlated because they share common clusterlevel random effects and similarly individuals who were nested with in a region were more correlated since they share common region-level random effects. Moreover, the variations on HIV testing that has been observed across clusters and regions were partly explained by individual and contextual background of socio-economic characteristics such as education, wealth index, age-group, mass media, knowledge on family planning, marital status and HIV/AIDS related stigma factors. Based on the findings of this study, the following recommendations are forwarded.

- Emphasizing on promoting HIV testing services for both men and women in the age groups of 20 to 34 years old, would greatly reduce the risk of HIV/AIDS

- Integrating family planning services with HIV testing could improve the proportion of both men and women that could be tested for HIV.

- Targeting on Somali region and Nuwer ethnic group (Gambella) while designing for HIV testing services would greatly reduce the risk of HIV/AIDS.

- It is highly important that future ethnographic research should investigate the observation found on Nuwer ethnic group by comparing with other ethnic groups in Ethiopia.

- The strengthening of the health programs on advocating the benefits of HIV testing through mass media (TV, radio or newspaper) might be helpful to reduce fear of stigma and discrimination amongst adults.

- Efficient distribution of health care facilities offering HIV testing services among women urban and rural residents are required

- Finally, the HIV/AIDS prevention and control programs in Ethiopia should focus on reducing HIV related stigma, improving educational level and creating awareness of the society on HIV testing through mass media at large in order to encourage people to get testing for HIV

\section{Competing Interests}

The author declares that he has no competing interests.

\section{Acknowledgments}

I am very grateful to MEASURE DHS authority that offered me all the necessary data used for this study.

\section{References}

1. Chan KC, Wong KH, Lee SS (2006) Universal decline in mortality in patients with advanced HIV-1 disease in various demographic subpopulations after the introduction of HAART in Hong Kong, from 1993 to 2002. HIV Med 7: 186-192.

2. (2003) Increasing Access to HIV Testing and Counselling: report of a WHO consultation, 19-21 November 2002. Geneva, Switzerland: World Health Organization.

3. Reniers G, Araya T, Davey G, Nagelkerke N, Berhane Y, et al. (2009) Steep declines in population- level AIDS mortality following the introduction of antiretroviral therapy in Addis Ababa, Ethiopia. AIDS 23: 511-518.

4. (2013) HIV testing and counseling services

5. (2004) Investing in a comprehensive health sector response to HIVIAIDS scaling up treatment and accelerating prevention. WHO.

6. (2001) HIVIAIDS Surveillance Report. Department of Health and Human Services, Centers for Disease Control and Prevention Atlanta, Georgia.

7. Valdiserri RO, Holtgrave DR, West GR (1999) Promoting early HIV diagnosis and entry into care. AIDS 13: 2317-2330.

8. Sherr L, Lopman B, Kakowa M, Dube S, Chawira G, et al. (2007) Voluntary counselling and testing: uptake, impact on sexual behaviour, and HIV incidence in a rural Zimbabwean cohort. AIDS 21: 851-860

9. Denison JA, O'Reilly KR, Schmid GP, Kennedy CE, Sweat MD (2008) HIV voluntary counseling and testing and behavioral risk reduction in developing countries: a meta-analysis, 1990-2005. AIDS Behav 12: 363-373.

10. (2008) HIV / AIDS in Ethiopia- An Epidemiological Synthesis World Bank Global HIVIAIDS Program. Washington DC, USA.

11. Maman S, Mbwambo J, Hogan NM, Kilonzo GP, Sweat M (2001) Women's barriers to HIV-1 testing and disclosure: challenges for HIV-1 voluntary counselling and testing. AIDS Care 13: 595-603.

12. (2012) Ethiopia Demographic and Health Survey (EDHS) 2011. ICF internationa Calverton, Maryland, USA: Central Statistical Authority, Addis Ababa, Ethiopia.

13. (2013) UNAIDS (2002): HIV voluntary counseling and testing: a gateway to prevention and care.

14. (2006) WHO: Towards universal access: Scaling up priority HIV/AIDS interventions in the health sector.

15. Lawn SD, Myer L, Orrell C, Bekker LG, Wood R (2005) Early mortality among adults accessing a community-based antiretroviral service in South Africa: implications for programme design. Aids 19: 2141-2148.

16. Korra A, Bejiga M, Tesfaye S (2005) Socio-demographic profile and prevalence of HIV infection among VCT clients in Addis Ababa. Ethiop J Health Dev 19

17. Simbayi LC, Kalichman SC, Skinner D, Jooste S, Cain D, et al. (2004) Theorybased HIV risk reduction counseling for sexually transmitted infection clinic patients in Cape Town, South Africa. Sex Transm Dis 31: 727-733.

18. Siziya S, Muula AS, Rudatsikira E, Mataya RH (2008) Correlates of HIV testing among women in Malawi: results from the 2006 Multiple Indicator Cluster Survey. Trop Med Int Health 13: 1351-1356

19. Weiser SD, Heisler M, Leiter K, Percy-de Korte F, Tlou S, et al. (2006) Routine HIV testing in Botswana: a population-based study on attitudes, practices, and human rights concerns. PLoS Med 3: e261.

20. Bwambale FM, Ssali SN, Byaruhanga S, Kalyango JN, Karamagi CA (2008) Voluntary HIV counselling and testing among men in rural western Uganda: implications for HIV prevention. BMC Public Health 8: 263.

1. Sweat M, Gregorich S, Sangiwa G, Furlonge C, Balmer D, et al. (2000) Costeffectiveness of voluntary HIV-1 counselling and testing in reducing sexual transmission of HIV-1 in Kenya and Tanzania. Lancet 356: 113-121.

22. Allen S, Tice J, Van de Perre P, Serufilira A, Hudes E, et al. (1992) Effect of serotesting with counselling on condom use and seroconversion among HIV discordant couples in Africa. BMJ 304: 1605-1609.

23. Rabe-Hesketh S,Skrondal A (2008) Multilevel and Longitudinal Modeling Using Stata (2ndedn). College Station, TX: Stata Press.

24. Lynch J, Kaplan G (2000) Socio-economic position. In Social epidiemiology. Edited by Berkman L, Kawachi I. New York: Oxford University Press, New York. 
Citation: Hailu TG (2016) A Multilevel Modeling Analysis of the Determinants and Cross-regional Variations of HIV Testing in Ethiopia: Ethiopian DHS 2011. J Biom Biostat 7: 277. doi:10.4172/2155-6180.1000277

Page 15 of 15

25. Gage AJ, Ali D (2005) Factors associated with self-reported HIV testing among men in Uganda. AIDS Care 17: 153-165.

26. Leta TH, Sandøy IF, Fylkesnes K (2012) Factors affecting voluntary HIV counselling and testing among men in Ethiopia: a cross-sectional survey. BMC Public Health 12: 438.

27. Namazzi J (2009) Determinants of using Voluntary Counselling and Testing for HIVIAIDS in Kenya. Monash University, Australia. 75: 135- 140.

28. Larose A, Moore S, Harper S, Lynch J (2011) Global income-related inequalities in HIV testing. J Public Health (Oxf) 33: 345-352.

29. Venkatesh KK, Madiba P, De Bruyn G, Lurie MN, Coates TJ, et al. (2011) Who gets tested for HIV in a South African urban township? Implications for test and treat and gender-based prevention interventions. J Acquir Immune Defic Syndr 56: 151-165.
30. Ramesh BM, Moses S, Washington R, Isac S, Mohapatra B, et al. (2008) Determinants of HIV prevalence among female sex workers in four south Indian states: analysis of cross-sectional surveys in twenty-three districts. AIDS 22 Suppl 5: S35-44.

31. Spaulding AB, Brickley DB, Kennedy C, Almers L, Packel L, et al. (2009): Linking family planning with HIVIAIDS interventions: a systematic review of the evidence. AIDS 1: S79-88.

32. Matovu JK, Makumbi FE (2007) Expanding access to voluntary HIV counselling and testing in sub-Saharan Africa: alternative approaches for improving uptake, 2001-2007. Trop Med Int Health 12: 1315-1322.

33. Denison JA, O'Reilly KR, Schmid GP, Kennedy CE, Sweat MD (2008) HIV voluntary counseling and testing and behavioral risk reduction in developing countries: a meta-analysis, 1990-2005. AIDS Behav 12: 363-373. 